Document downloaded from:

http://hdl.handle.net/10251/68520

This paper must be cited as:

Ferrer, J.; Pretel, R.; Durán Pinzón, F.; Giménez, J.; Robles Martínez, A.; Ruano García, MV.; Serralta Sevilla, J.... (2015). Design methodology for submerged anaerobic membrane bioreactors (AnMBR): A case study. Separation and Purification Technology. 141:378-386. doi:10.1016/j.seppur.2014.12.018.

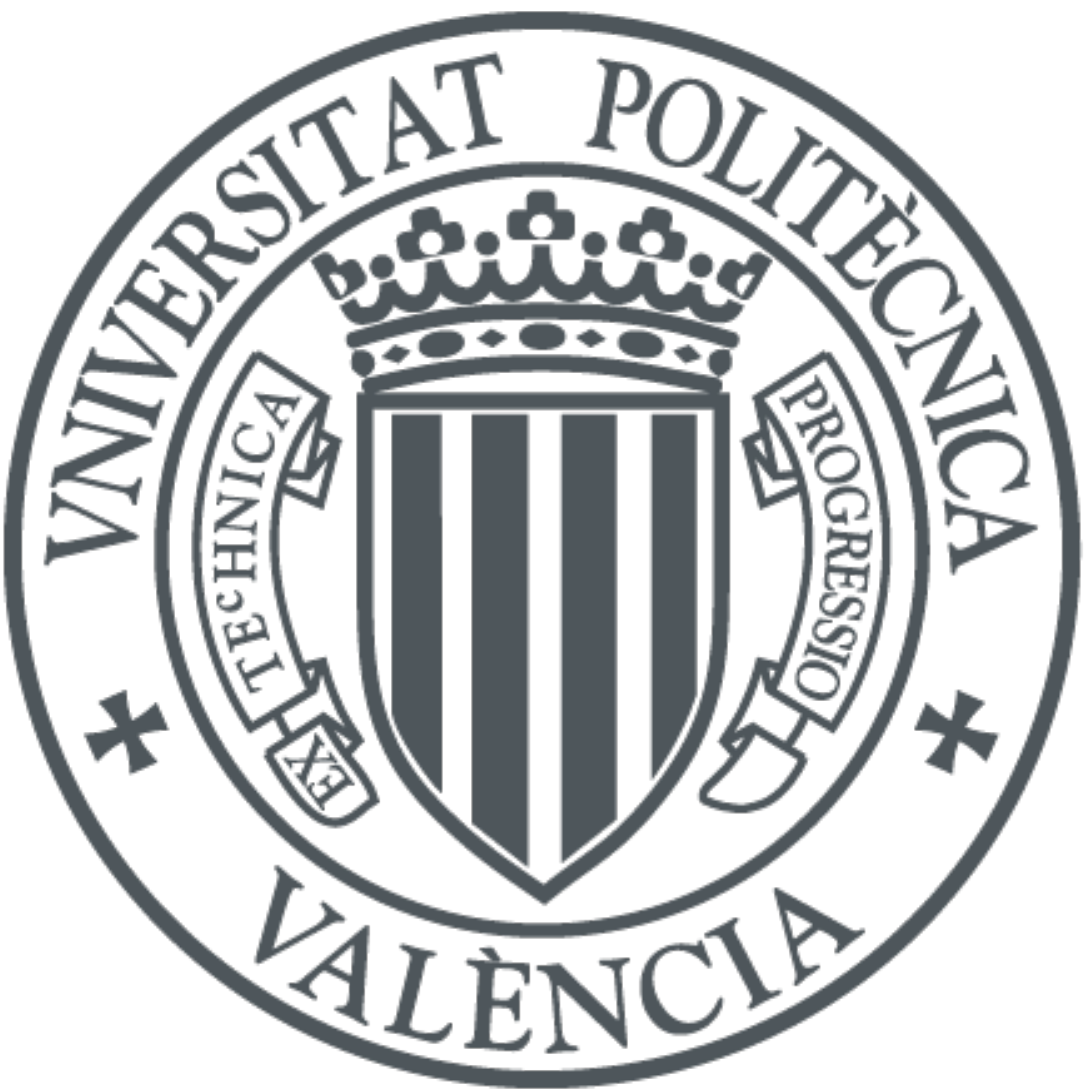

The final publication is available at

http://dx.doi.org/10.1016/j.seppur.2014.12.018

Copyright Elsevier

Additional Information 


\title{
Design methodology for submerged anaerobic membrane bioreactors (AnMBR): A case study
}

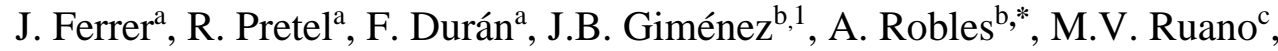 \\ J. Serralta ${ }^{a}$ J. Ribes ${ }^{b}$ and A. Seco ${ }^{b}$ \\ a Institut Universitari d'Investigació d'Enginyeria de l'Aigua i Medi Ambient, IIAMA, \\ Universitat Politècnica de València, Camí de Vera s/n, 46022 Valencia, Spain (e-mail: \\ jferrer@hma.upv.es; rutprejo@upv.es; fredurpi@upv.es; jserralt@hma.upv.es)

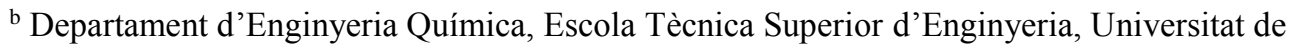 \\ València, Avinguda de la Universitat s/n, 46100 Burjassot, Valencia, Spain (e-mail: \\ juan.b.gimenez@uv.es; angel.robles@uv.es; josep.ribes@uv.es; aurora.seco@uv.es) \\ ${ }^{\mathrm{c}}$ FCC Aqualia, S.A., Avenida del Camino de Santiago, 4028050 Madrid, Spain (e-mail: \\ mavictoria.ruano.garcia@fcc.es) \\ * Corresponding author: tel. +34 9638799 61, e-mail: angel.robles@uv.es
}

\begin{abstract}
The main objective of this study is to propose guidelines for designing submerged anaerobic MBR (AnMBR) technology for municipal wastewater treatment. The design methodology was devised on the basis of simulation and experimental results from an AnMBR plant featuring industrial-scale hollow-fibre membranes. The proposed methodology aims to minimise both capital expenditure and operating expenses, and the key parameters considered were: hydraulic retention time, solids retention time, mixed liquor suspended solids concentration in the membrane tank, $20^{\circ} \mathrm{C}$-standardised critical flux, specific gas demand per square metre of membrane area, and flow of sludge being recycled from the membrane tank to the anaerobic reactor. An AnMBR WWTP operating at 15 and $30^{\circ} \mathrm{C}$ with both sulphate-rich (5.7 $\left.\mathrm{mg} \mathrm{COD} \cdot \mathrm{mg}^{-1} \mathrm{SO}_{4}-\mathrm{S}\right)$ and low-sulphate $\left(57 \mathrm{mg} \mathrm{COD} \cdot \mathrm{mg}^{-1} \mathrm{SO}_{4}-\mathrm{S}\right)$ municipal wastewater was designed. The minimum cost of the designed plant was $€ 0.097$ and $€ 0.070$ per $\mathrm{m}^{3}$ when treating sulphate-rich and low-sulphate wastewater,
\end{abstract}

\footnotetext{
${ }^{1}$ Present address: FCC Aqualia, S.A., Avenida del Camino de Santiago, 4028050 Madrid, Spain
} 
respectively.

\author{
Keywords \\ CAPEX/OPEX; design methodology; industrial-scale hollow-fibre membranes; \\ submerged anaerobic MBR (AnMBR); municipal wastewater treatment
}

\title{
1. Introduction
}

Anaerobic wastewater treatment has several advantages in comparison with conventional aerobic treatment: i) lower sludge production because of the low yield of anaerobic microorganisms; ii) lower energy consumption because no aeration is required; and iii) potential resource recovery because energy (from biogas production) and nutrients $\left(\mathrm{NH}_{4}{ }^{+}\right.$and $\left.\mathrm{PO}_{4}{ }^{3-}\right)$ can be obtained from the anaerobic degradation process. As a result, anaerobic processes are viewed as an attractive choice for sustainable lowstrength wastewater treatment (e.g. municipal wastewater). However, anaerobic processes have certain drawbacks that currently prevent them from being used in the full-scale treatment of low-strength wastewater.

As regards the anaerobic treatment of municipal wastewater, the low COD (chemical oxygen demand) of municipal wastewater (typically less than $1 \mathrm{~g} \cdot \mathrm{L}^{-1}$ ) means that little methane is produced. Therefore, an external energy source would be needed to heat the reactor to mesophilic conditions [1]. At low temperatures, the growth rates of anaerobic microorganisms are greatly reduced and long sludge retention times (SRT) are necessary - not only to meet appropriate effluent and sludge standards and produce considerable amounts of biogas, but also to prevent biomass washout [2]. Therefore, the success of anaerobic treatment of municipal wastewater at low temperatures depends on the ability to detach SRT from hydraulic retention time (HRT). In this respect, submerged anaerobic membrane bioreactors (AnMBRs) are considered a feasible 
alternative for municipal wastewater treatment at low temperatures.

Jeison [3] reported reductions of up to $90 \%$ in the sludge produced when AnMBR technology was used, therefore this technology is a promising alternative for the anaerobic treatment of low-strength wastewater. In addition, depending on the operating conditions, the produced sludge could be enough stabilised to be disposed of directly on farmland with no further digestion step (no pathogens and low biological methane production).

On the other hand, when municipal wastewater containing sulphate is anaerobically treated, the sulphate is reduced to sulphide. The production of this end product can cause technical problems such as: i) hydrogen sulphide is toxic to anaerobic microorganisms; ii) the amount of biogas produced is reduced because some of the influent COD (approx. $2 \mathrm{~g}$ COD per $\mathrm{g} \mathrm{SO}_{4}-\mathrm{S}$ ) is consumed by sulphate-reducing microorganisms (SRB); iii) the quality of the produced biogas is reduced because some of the hydrogen sulphide produced will end up in the biogas; iv) hydrogen sulphide can cause corrosion in pipes, engines and boilers, entailing higher maintenance and replacement costs; and v) downstream oxygen demand may be required for oxidising hydrogen sulphide. For municipal wastewater, which can easily present low $\mathrm{COD} / \mathrm{SO}_{4}-$ S ratios, the competition between Methanogenic Archaea (MA) and SRB can critically affect the amount and quality of the biogas produced. According to the theoretical methane yield under standard temperature and pressure conditions $\left(350 \mathrm{~L} \mathrm{CH}_{4}\right.$ per $\mathrm{kg}$ $\mathrm{COD}), \mathrm{SRB}$ reduces the production of approx. $700 \mathrm{~L}$ of methane per $\mathrm{kg}$ of influent $\mathrm{SO}_{4}-\mathrm{S}$ (considering reduction of all sulphate to sulphide). Therefore, higher biogas productions would be achieved at low sulphate influent concentrations [4]. 
As regards filtration, the high SRTs applied in AnMBR technology usually mean high levels of mixed liquor suspended solids (MLSS) which contribute to membrane fouling [5]. In order to minimise any kind of membrane fouling and thereby increase membrane lifespan, the main operating challenge for AnMBRs is to optimise membrane operation and configuration $[6,7,8]$. It is therefore necessary to optimise filtration whilst minimising not only capital expenditure but also operating and maintenance costs. Hence the AnMBR design strategy must be carefully selected since depending on the design strategy, different design criteria can be adopted.

The main points of fouling control strategies as regards membrane operation are: optimising the frequency and duration of the physical cleaning stages (back-flush and relaxation) $[9,10]$; optimising different operating variables such as gas sparging intensity or permeate/influent flow rate ratios; and operating membranes under the subcritical filtration conditions bounded by critical flux $\left(\mathrm{J}_{\mathrm{C}}\right)[11,12]$. Thus, one such design strategy entails operating membranes in sub-critical filtration conditions. Operating membranes sub-critically increases membrane lifespan, which reduces maintenance costs, but it usually increases investment and/or operating expenses (i.e. it increases the membrane area needs and/or the intensity of the gas sparging used for membrane scouring). MLSS and gas sparging intensity (usually measured as specific gas demand per membrane area, $S G D_{m}$ ) have been widely identified as the factors that affect $J_{C}$ most. As for MLSS, an optimum combination of reactor volume and filtration area must be selected in order to keep MLSS at sub-critical levels for a given $S G D_{m}$. In addition, membrane scouring by air/biogas is a key process that allows minimising energy consumption of MBR plants because it is the most energy-consuming process in fullscale MBRs (see, for instance, [12]). Therefore, one of the main challenges when designing an AnMBR plant is to achieve acceptable membrane performances at 
minimum levels of $S G D_{m}$ whilst minimising membrane fouling.

Another design criterion entails operating membranes in supra-critical filtration conditions. This strategy means lower initial investment because it requires lower operating volumes (i.e. operating at higher MLSS levels) and/or smaller membrane surfaces than operating membranes at sub-critical filtration conditions. However, maintenance and operating expenses are probably higher. For instance, for a given $S G D_{m}$, an increase in MLSS usually means greater membrane fouling, which in turn increases membrane maintenance costs because the membranes are chemically cleaned more often. In addition, increasing the frequency of membrane chemical cleaning affects the membrane lifespan, which also increases membrane replacement costs.

Although AnMBR technology has not been yet applied to full-scale municipal wastewater treatment, recent literature $[13,14,15,16,17]$ has reported increasing interest by the scientific community in the use of AnMBRs for municipal wastewater treatment. However, a design methodology that holistically considers the key operating factors that affect both biology and filtration is still necessary in order to lay the foundations for the optimum design of full-scale AnMBRs for municipal wastewater treatment. The aim of this paper is to provide guidelines for designing AnMBR technology under different scenarios. To this aim, a design methodology was developed based on the knowledge and operation experience gained from an AnMBR plant featuring industrial-scale hollow-fibre membranes that was fed with sulphate-rich wastewater from the pre-treatment of a municipal WWTP located in Valencia (Spain). The proposed methodology aims to minimise total annual costs, which are defined as the sum of capital and operating expenses (CAPEX/OPEX). OPEX take into account energy requirements, methane production and capture, sludge handling and disposal, 
and membrane maintenance and replacement. In this respect, the key operating parameters considered when designing the biological process were hydraulic retention time $(H R T)$ and solids retention time (SRT); and, when designing the filtration process, the levels of mixed liquor suspended solids in the membrane tank $\left(M L S S_{M T}\right)$, the $20^{\circ} \mathrm{C}$ standardised critical fluxes $\left(J_{20}\right), S G D_{m}$ and the recycling sludge flow rate from the membrane tank to the anaerobic reactor $\left(Q_{\text {rec }}\right)$.

The proposed methodology was used to design an AnMBR WWTP handling municipal wastewater with high and low levels of sulphate $\left(5.7\right.$ and $57 \mathrm{mg}$ COD $\cdot \mathrm{mg}^{-1}$ $\mathrm{SO}_{4}-\mathrm{S}$, respectively) at 15 and $30^{\circ} \mathrm{C}$.

\section{Materials and methods}

As mentioned earlier, the proposed design methodology is based on the knowledge and the results obtained from the operation of an AnMBR plant fitted with industrialscale membranes that was operated using real sulphate-rich municipal wastewater. The WWTP simulating software DESASS [18], which enables a wide range of wastewater treatment schemes (including AnMBR systems) to be evaluated, was used to simulate the AnMBR WWTP.

\subsection{AnMBR plant description}

The AnMBR plant consists of an anaerobic reactor with a total volume of $1.3 \mathrm{~m}^{3}$ connected to two membrane tanks, each with a total volume of $0.8 \mathrm{~m}^{3}$. Each membrane tank features one ultrafiltration hollow-fibre membrane commercial system (PURON®, Koch Membrane Systems, $0.05 \mu \mathrm{m}$ pore size, and outside-in filtration). Each module consists of 9 hollow-fibre bundles of 1.8-m length that give a total of $30 \mathrm{~m}^{2}$ membrane surface. In order to scour the membranes, thus minimising cake layer formation, a 
fraction of the produced biogas is continuously recycled to the membrane tanks through the bottom of each fibre bundle.

As mentioned above, this plant was fed with sulphate-rich municipal wastewater from the pre-treatment of the Carraixet WWTP (Valencia, Spain), which involves screening, degritting and grease removal. Further details of this AnMBR can be found in Giménez et al. [19] and Robles et al. [9].

\subsection{AnMBR plant operation}

The AnMBR plant was operated for more than 4 years under different operating conditions $[4,9]$. Regarding the biological process, the plant was operated at four different SRT (20, 30, 40 and 70 days), with controlled HRT ranging from 5 to 30 hours, and organic load rates (OLR) ranging from 0.5 to $2 \mathrm{~kg} \mathrm{COD} \cdot \mathrm{m}^{-3} \cdot \mathrm{d}^{-1}$. The impact of temperature on process performance was evaluated in the $14-33^{\circ} \mathrm{C}$ range. During the operating period, the $\mathrm{pH}$ in the mixed liquor remained stable around $6.8 \pm 0.2$. As regards filtration, the membranes were operated at $J_{20}$ from 6 to $20 \mathrm{LMH}$ and $\mathrm{SGD}_{\mathrm{m}}$ from 0.1 to $0.5 \mathrm{~m}^{3} \cdot \mathrm{h}^{-1} \cdot \mathrm{m}^{-2}$. The MLSS ranged from 5 to $30 \mathrm{~g} \cdot \mathrm{L}^{-1}$.

The influent wastewater was characterised using 24-hour composite samples. The following parameters were analysed daily: Total Suspended Solids (TSS), Volatile Suspended Solids (VSS), Volatile Fatty Acids (VFA), carbonate alkalinity (Alk), sulphate $\left(\mathrm{SO}_{4}-\mathrm{S}\right)$, ammonium $\left(\mathrm{NH}_{4}-\mathrm{N}\right)$, and orthophosphate $\left(\mathrm{PO}_{4}-\mathrm{P}\right)$. The following parameters were determined once a week: total and soluble COD (T-COD and S-COD, respectively); total and soluble biological oxygen demand (T-BOD 20 and $\mathrm{S}-\mathrm{BOD}_{20}$, respectively); and total nitrogen (TN) and total phosphorous (TP). Solids, COD, sulphate, and nutrients were determined according to Standard Methods [20]. Alk and 
VFA were determined by titration using the method proposed by WRC [21].

\subsection{AnMBR WWTP simulation}

Figure 1 shows a flow diagram of the AnMBR WWTP designed to remove organic matter, which is based on the AnMBR plant mentioned earlier. The proposed AnMBR WWTP also includes a sludge dewatering system for conditioning the resulting sludge; a degassing membrane for capturing the dissolved methane in the effluent, and a combined heat and power (CHP) system enabling energy to be recovered from methane. This plant was simulated using a new version of DESASS [18] which features a modified version of the mathematical model BNRM2 [22] including the competition between both acetogenic and methanogenic microorganisms and sulphate-reducing microorganisms [23]. This mathematical model was validated beforehand using experimental data obtained from the AnMBR plant [23].

The proposed AnMBR was designed to handle an influent flow of $50,000 \mathrm{~m}^{3} \cdot \mathrm{d}^{-1}$ with the characteristics shown in Table A.1. Two different simulation scenarios were evaluated: the treatment of (1) sulphate-rich municipal wastewater $\left(5.7 \mathrm{mg} \mathrm{COD} \cdot \mathrm{mg}^{-1}\right.$ $\mathrm{SO}_{4}-\mathrm{S}$ ) and (2) low-sulphate municipal wastewater (57 $\mathrm{mg} \mathrm{COD} \cdot \mathrm{mg}^{-1} \mathrm{SO}_{4}-\mathrm{S}$ ).

\section{Design methodology}

In the proposed methodology, HRT, SRT and $M L S S_{M T}$ are the key operating parameters when designing the biological process in AnMBR technology, and $\boldsymbol{J}_{20}$, $S G D_{m}$ and $M L S S_{M T}$ are the key operating parameters when designing the filtration process in AnMBR technology.

The design methodology proposed in this study (summarised in Figure A.1) aims to 
minimise total annual costs (CAPEX plus OPEX), and consists of two main stages. The first stage involves optimising two parameters related to the anaerobic reactor, i.e. anaerobic reactor volume $(V)$ and sludge recycling flow rate from the membrane tank to the anaerobic reactor (i.e. $Q_{r e c}$ ). At a given operating temperature and influent flow and load, the AnMBR system is simulated under different SRT and $M L S S_{M T}$ (for $Q_{\mathrm{rec}}=$ influent flow). The SRT values used in the simulations must be above the minimum SRT needed to meet effluent standards and sludge stabilisation criteria. These simulation results are used to determine the optimum combination of anaerobic reactor volume and sludge recycling flow rate (see 3.1) for each SRT and $M L S S_{M T}$. The optimum combination $\left(V(o p t), Q_{\text {rec }}(o p t)\right)$ is the one that gives the lowest anaerobic reactor cost, including the following cost items: construction of the anaerobic reactor including pumps and pipes, and the energy required for reactor stirring and sludge pumping. The cost of the biological process is then calculated for each SRT and $M L S S_{M T}$, also taking into account the costs of sludge handling and disposal, and the savings made by recovering energy from methane capture.

The second stage involves optimising $J_{20}$ at the different $M L S S_{M T}$ levels evaluated in the simulations of stage 1 . Before applying this methodology, the $20^{\circ} \mathrm{C}$-standardised critical flux $\left(J_{C 20}\right)$ must be experimentally determined at different $M L S S_{M T}$ and $S G D_{m}$. The $S G D_{m}$ considered in this study was selected on the basis of previous experimental results (data not shown), and $J_{C 20}$ was calculated for the different $M L S S_{M T}$. The following variables are then calculated for different values of $J_{20}$ above and below $J_{C 20}$ : membrane tank volume, membrane filtration area $\left(A_{m}\right)$, flow rate of biogas recycled into membrane tank $\left(Q_{G}\right)$, transmembrane pressure $(T M P)$, membrane permeability $(K)$ and the amount of chemical reagents required for chemical membrane cleaning recommended by the membrane manufacturer. These values are then used to calculate 
the filtration cost, taking into account the following cost items: membrane area, membrane tank, biogas sparging, blowers and pipes, permeate pumping, chemical reagent, and membrane replacement. Then, for each level of $M L S S_{M T}$ the optimum operating $J_{20}\left(J_{20}(o p t)\right)$ is selected, which is the one that gives the lowest filtration cost.

Finally, the optimum design values ( $S R T, H R T, Q_{r e c}, \mathrm{MLSS}_{\mathrm{MT}}, J_{20}$ and $\left.A_{m}\right)$, i.e. those giving the lowest total cost, in worst-case seasonal conditions (i.e. winter) are selected, and then the optimum operating strategy for the best-case scenario (i.e. summer) is established.

\subsection{Biological process design}

Table 1a shows how the selected design criteria (SRT, $Q_{\text {rec }}, M L S S_{M T}$ ) affects the above-mentioned factors that contribute to the cost of the biological process. As Table 1a shows, higher SRTs increase construction and stirring costs but also increase biogas production, resulting in more energy being recovered from methane capture. Increases in $Q_{\text {rec }}$ reduce the reactor volume for a given $M L S S_{M T}$, but increase the sludge pumping cost. Therefore, the optimum AnMBR design must include the optimum combination of SRT and $Q_{r e c}$. Finally, the higher the $M L S S_{M T}$, the lower the reactor volume and stirring costs. However, an increase in $M L S S_{M T}$ leads to higher filtration costs. Since the costs of the biological and filtration processes depend on MLSS levels, the design and operation of both the anaerobic reactor and the membrane tank must be simultaneously optimised for different $M L S S_{M T}$. The range of 5 to $25 \mathrm{~g} \cdot \mathrm{L}^{-1}$ used in this paper was adopted on the basis of experimental data from the AnMBR plant.

The performance of the anaerobic reactor at each $M L S S_{M T}$ must be simulated at different SRT and $Q_{r e c}$. SRT values should be above the minimum SRT stipulated in 
effluent standards and sludge stabilisation criteria.

At a given SRT and $M L S S_{M T}$, the higher the sludge recycling flow rate, the lower the reactor volume. Our study found the following relationship between the anaerobic reactor volume and the sludge recycling flow rate (see Equation 1):

$$
\frac{V}{V^{\prime}}=a+\frac{b}{R_{r e c}}-\frac{c}{R_{r e c}{ }^{2}}+\frac{d}{R_{r e c}{ }^{3}}
$$

where $V$ is the reactor volume, $R_{\text {rec }}$ is the sludge recycling ratio defined as $Q_{\text {rec }}$ per influent flow, $V$ ' is the reference reactor volume obtained for $R_{\text {rec }}=1$, and a, b, c and d are fine-tuning parameters (in this study, $0.5039,0.5003,4.2453 \cdot 10^{-3}$ and $3.2861 \cdot 10^{-5}$, respectively, obtained from the simulation results shown in Figure 2).

The correlation shown in Equation 1 significantly reduces the number of simulations required to obtain optimum design values. In this respect, the performance of the biological process at each selected $M L S S_{M T}$ is simulated at different SRTs for $Q_{\text {rec }}$ $=$ influent flow $\left(R_{\text {rec }}=1\right)$, which gives the defined reference reactor volume $V^{\prime}$. Different $R_{\text {rec }}$ are then selected for each $M L S S_{M T}$ and $S R T$, and the respective anaerobic reactor volumes $(V)$ are calculated using Equation 1 (with the $\mathrm{V}^{\prime}$ previously determined and each of the $R_{\text {rec }}$ selected). The optimum combination of $R_{\text {rec }}$ and $V$ is the one that gives the lowest anaerobic reactor cost taking into account the following cost items: anaerobic reactor construction including pumps and pipes, anaerobic reactor stirring (including equipment and energy requirements) and sludge pumping.

The different simulations carried out during the biological process design give the following information that is used to calculate the capital and operating expenses of the 
biological process: anaerobic reactor volume, sludge recycling flow rate, biogas production, and flow rate and characteristics of the wasted sludge.

\subsection{Filtration design}

As mentioned earlier, the cost of the following items was taken into account when calculating filtration costs: membrane area, membrane tank including blowers and pipes, biogas sparging, permeate pumping (including equipment and energy requirements), chemical reagent and membrane replacement. The main operating parameters that affect filtration costs are $J_{20}, M L S S_{M T}$ and $S G D_{m}$. Table $1 \mathrm{~b}$ shows the effect of these operating parameters on the above-mentioned costs.

As Table $1 \mathrm{~b}$ shows, the lower the $M L S S_{M T}$, the lower the filtration cost. However, as stated before, the higher the $M L S S_{M T}$, the lower the cost of the biological process. Therefore, the sum of the biological and filtration costs must be minimised by optimising $M L S S_{M T}$. To do so, the filtration cost was calculated for each $M L S S_{M T}$ at different $J_{20}$ values above and below the experimentally-determined critical flux $\left(J_{20}\right.$ varying from 80 to $120 \%$ of the respective $J_{C 20}$ ).

Filtration costs were calculated in each scenario using the following parameters: membrane tank volume, membrane filtration area $\left(A_{m}\right.$, Equation 2$)$, membrane permeability ( $K$, Equation 3), transmembrane pressure (TMP, Equation 4) and the biogas recycling flow rate $\left(Q_{\text {gas }}\right.$, Equation 5):

$$
\left[A_{m}\right]_{i, k}=\frac{Q_{i n}}{\left[J_{20}\right]_{i, k}}
$$


where $\left[A_{m}\right]_{i, k}$ is the membrane filtration area for each $M L S S_{M T}$ (denoted by $i$ ) and $\% J_{20, C}$ (denoted by $k$ ), $Q_{\text {in }}$ is the influent flow rate, and $\left[J_{20}\right]_{i, k}$ is the $20{ }^{\circ} \mathrm{C}$-standardised transmembrane flux for each $i$ and $k$.

$$
\left.[K]_{i}=-a \cdot \mid M L S S_{M T}\right\rfloor_{i}+b
$$

Equation 3

where $[K]_{i}$ is the membrane permeability in $\mathrm{LMH} \cdot \mathrm{bar}^{-1}$ for each level of mixed liquor suspended solids in the membrane tank (denoted by $\left[M L S S_{M T}\right]_{i}$ ), and $a$ and $b$ are fine-tuning parameters obtained from previous studies [24].

$$
[T M P]_{i, k}=\frac{\left\lfloor J_{20}\right\rfloor_{i, k}}{[K]_{i}}
$$

where $[T M P]_{i, k}$ is the transmembrane pressure for each $M L S S_{M T}$ (denoted by $i$ ) and $\% J_{20, C}$ (denoted by $k$ ), $\left[J_{20}\right]_{i, k}$ is the $20{ }^{\circ} \mathrm{C}$-standardised transmembrane flux of each $i$ and $k$, and $[K]_{i}$ is the membrane permeability of each $i$.

$$
\left\lfloor Q_{G}\right\rfloor_{i, k}=S G D_{m} \cdot\left\lfloor A_{m}\right\rfloor_{i, k}
$$

where $\left[Q_{G}\right]_{i, k}$ is the biogas recycling flow rate for each $M L S S_{M T}$ (denoted by $i$ ) and each $\% J_{20, C}$ (denoted by $k$ ), $S G D_{m}$ is the specific gas demand per membrane area, and $\left[A_{m}\right]_{i, k}$ is the membrane filtration area for each $i$ and $k$.

The results obtained from equations 2 to 5 were used to calculate the capital and operating expenses of filtration process.

\subsection{Total annual cost}

The total annual cost $(T A C)$ of the biological and filtration processes was calculated 
by adding the annual investment cost $(I C)$ to the annual operating and maintenance costs $(O \& M C)$, as shown in Equation 6 [25]:

$$
T A C=\frac{\mathrm{r}(1+\mathrm{r})^{\mathrm{t}}}{(1+r)^{t}-1} \cdot I C+O \& M C
$$

where $T A C$ is the total annual cost, $I C$ is the investment cost, $O \& M C$ are the annual operating and maintenance costs, $r$ is the annual discount rate, and $t$ is the depreciation period in years.

The IC of the proposed AnMBR WWTP includes construction work (anaerobic reactor and membrane tank) and equipment (membranes, blowers, pumps and pipes). The $O \& M C$ of the proposed AnMBR WWTP includes energy requirements, energy recovery from methane capture, chemical reagents used to clean membranes, and sludge handling and disposal. Maintenance expenditure refers to the pumps and blowers, and membrane replacement.

\section{Case study}

The proposed methodology was used to design an AnMBR WWTP handling sulphate-rich wastewater at 15 and $30^{\circ} \mathrm{C}$. Firstly, the optimum design parameters were determined for this AnMBR WWTP under the worst-case operating conditions $\left(15^{\circ} \mathrm{C}\right)$, and then the optimum operating strategy was calculated for the best-case operating conditions $\left(30^{\circ} \mathrm{C}\right)$.

Table A.2 shows the unit costs used to calculate the capital and operating expenses (CAPEX/OPEX) of the proposed AnMBR WWTP. The main considerations taken into 
account when calculating CAPEX and OPEX are summarized as follows:

- Capital/investment cost (IC):

- Depreciation: A depreciation period of 20 years was used to calculate the total annual cost (TAC), with an annual discount rate $(r)$ of $5 \%$.

- Membrane tank: The membrane tank volume was estimated according to a commercial membrane unit (PURON ${ }^{\circledR}$, Koch Membrane Systems, PURPSH1500, $0.05 \mu \mathrm{m}$ pore size, $1500 \mathrm{~m}^{2}$ total filtering area).

- Biogas, sludge and permeate pipeline: The velocity of the fluids in the pipes was set to $1 \mathrm{~m} \cdot \mathrm{s}^{-1}$ to calculate the pipe diameter.

- Operating cost $(O C)$ :

○ Power requirements: The simulation software DESASS was used to calculate the power requirements of the sludge and permeate pumps (associated with the filtration and back-flushing phases), biogas blowers, anaerobic reactor stirrers and sludge dewatering system as shown in Pretel et al. [26].

$\circ \quad$ Energy recovery from methane (biogas methane and dissolved methane in the effluent): The selected technology for capturing the dissolved methane in the effluent was degassing membranes (see Table A.2). The chosen CHP technology for energy recovery from methane consisted of microturbines. The power and heat efficiency of this technology is approximately 27.0 and $33.5 \%$, respectively [27].

- Chemical reagents used to clean membranes: According to Judd and Judd [6] and previous experiments (see, for instance, [28]), 9.5 months can be set as the interval for membrane cleaning with chemicals when operating under critical filtration conditions. Therefore, in this study, the membrane chemical cleaning frequency ranged from 2 months (operating at $J_{20}=120 \%$ of $J_{C 20}$ ) to 18 months 
(operating at $J_{20}=80 \%$ of $J_{C 20}$ ). Sodium hypochlorite and citric acid are the two reagents required for cleaning the membranes chemically. In compliance with the membrane cleaning protocol proposed by the membrane manufacturer, $2000 \mathrm{ppm}$ was adopted as the dose of both sodium hypochlorite and citric acid and the contact with each chemical was set to 5 hours.

- Membrane physical cleaning: The downtime for membrane physical cleaning through back-flushing was set to $2.4 \%$ of the membrane operating time. This downtime was established based on the experimental results obtained by a modelbased supervisory controller implemented in the AnMBR plant which optimised, among others, back-flushing frequency [10].

Membrane replacement cost: As regards membrane lifespan, the cost of replacing the membrane was contemplated in order to evaluate the entire lifecycle cost of the system. The maximum total contact with chlorine permissible before membrane replacement according to the supplier is 500,000 ppm-hours cumulative. Therefore, the membrane lifetime (determining the membrane replacement cost) was calculated accounting for: 1) the maximum total contact with chlorine permissible and 2) the interval for membrane chemical cleaning.

○ $\quad$ Sludge treatment cost: Centrifuges were selected for sludge dewatering. To ensure adequate sludge conditioning, polyelectrolyte is required and the dose considered in our study was $6 \mathrm{~kg} \cdot \mathrm{t}^{-1}$ TSS [29]. The sludge produced was used as fertiliser on farmland.

○ Equipment replacement and maintenance: The lifetime of blowers and pumps was as per manufacturers' recommendations (see Table A.2). Membrane lifetime was estimated according to the total chlorine contact specified by the manufacturer (see Table A.2). 


\subsection{Simulation results.}

Figure 3a shows the simulation results of the effect of SRT on the biodegradable volatile suspended solids (BVSS) fraction of the sludge and on methane production, at 15 and $30^{\circ} \mathrm{C}$. This figure shows that the BVSS fraction falls and methane production rises when either the temperature or SRT increases. As Figure 3a illustrates, an SRT of more than 10 days would be necessary in order to comply with the sludge stabilisation criteria (\%BVSS $<35 \%$ ) at $30{ }^{\circ} \mathrm{C}$, whereas the minimum SRT required at $15{ }^{\circ} \mathrm{C}$ would increase up to 35 days.

However, at $15^{\circ} \mathrm{C}$ no methane production is envisaged on the basis of the model with SRTs of less than 35 days. In sulphate-rich wastewaters, methanogenic and sulphate-reducing organisms compete for the available substrates. In this respect, the available substrates will be consumed first by sulphate-reducing organisms because their growth rate is higher than methanogenic organisms.

Figure $3 \mathrm{~b}$ shows the simulation results of the effect of SRTs on effluent COD and BOD (excluding methane COD) at 15 and $30^{\circ} \mathrm{C}$. The upper and lower horizontal lines mark the COD and BOD discharge limits, respectively, as specified by European discharge quality standards. As can be seen in Figure 3b, the COD and BOD of the effluent are both forecast to be well below said standards in the ranges of SRT and temperature used in our simulations. These results indicate that the membrane retention capacity will enable effluent of a good quality, i.e. containing acceptable levels of organic matter, to be obtained across a wide range of SRTs and temperatures.

\subsection{Optimum design in winter conditions}

Figure 4 a shows the total annual filtration cost (CAPEX and OPEX) per cubic 
meter of treated water with a gas sparging intensity of $0.1 \mathrm{~m}^{3} \cdot \mathrm{h}^{-1} \cdot \mathrm{m}^{-2}, M L S S_{M T}$ ranging from 5 to $25 \mathrm{~g} \cdot \mathrm{L}^{-1}$ and $J_{20}$ below and above the critical flux ( $J_{20}$ varying from 80 to $120 \%$ of $J_{C 20}$ ). On the basis of the results of our experiments, we set $S G D_{m}$ to $0.1 \mathrm{~m}^{3} \cdot \mathrm{h}^{-}$ ${ }^{1} \cdot \mathrm{m}^{-2}$ in this study because this value gave adequate long-term membrane performance within the range of operating conditions evaluated, whilst resulting in minimum operating costs.

Figure 4a illustrates a similar tendency in the filtration costs at each $M L S S_{M T}$ evaluated, with minimum costs occurring when the operating transmembrane flux was around the critical flux $\left(J_{20}=\right.$ approx. $\left.100-110 \% J_{C 20}\right)$. Operating at critical fluxes above this value (approx. $115-120 \% J_{C 20}$ ) significantly increases filtration costs. In this respect, although operating at a high $J_{20}$ reduces both the energy needed to scour the membrane with biogas and the membrane area investment cost, operating at high $J_{20}$ commonly means high membrane chemical cleaning frequencies. This causes a high consumption of chemical reagents and a lower membrane lifetime, and hence higher membrane maintenance costs.

Figure $4 \mathrm{~b}$ illustrates the main items that are included in total filtration costs, i.e. membrane area (approx. 55\% of total filtration costs); membrane scouring by biogas (approx. 28\% of total filtration costs); chemical reagents for membrane cleaning (approx. 14\% of total filtration costs); and others which include the cost of: membrane tank (including the land required), blowers, permeate pumps, pipeline system and permeate pumping (approx. $3 \%$ of total filtration costs). As Figure $4 \mathrm{~b}$ shows, filtration costs decrease as $M L S S_{M T}$ decreases. However, as mentioned earlier, the cost of the biological process increases as $M L S S_{M T}$ decreases. 
Figure 5 shows how (a) SRT and (b) $M L S S_{M T}$ affect the total cost, the biological process cost and the filtration process cost of the proposed AnMBR WWTP $\left(€\right.$ per $\left.\mathrm{m}^{3}\right)$ in two cases, i.e. (i) no methane capture, and (ii) energy recovered from methane (biogas methane and methane dissolved in the effluent). As Figure 5a shows, biological process costs are lowest when the SRT that enables the sludge stabilisation criterion to be met is also lowest (see Figure 3a), a criterion defined in this study as when the BVSS sludge content is $35 \%$. It is important to note that an increase in SRT requires a higher reactor volume in order to maintain a given level of $M L S S_{M T}$. This increase in the reactor volume affects not only investment costs but also the operating costs of the biological process (i.e. stirring costs). As a result, the higher methane production observed when SRT was increased (see Figure 3a) did not offset the higher total cost caused by increasing the reactor volume. Hence, the optimum operating SRT in winter was 35 days - which tallies with the minimum SRT mentioned earlier that enables sludge stabilisation criteria to be met.

It is worth to point out that when treating sulphate-rich municipal wastewater at 15 ${ }^{\circ} \mathrm{C}$, until reaching an SRT of around 45 days the total cost of the system when capturing methane was higher than the cost when methane was not captured (see Figure 5a). These results are caused by the low methane productions achieved when operating at SRTs below 45 days, which did not offset the cost of the technology considered for recovering energy from methane (degassing membranes and CHP). Nevertheless, recovering the dissolved methane from the effluent is necessary for making feasible the implementation of AnMBR technology at full-scale, so as to minimise the greenhouse potential impact resulting from discharging significant concentrations of methane (a powerful greenhouse gas) with the effluent. 
As Figure 5b illustrates, filtration costs rise as $M L S S_{M T}$ increases. This result is due to the increase in both investment costs (mainly related to the required membrane area) and operating and maintenance costs (mainly related to membrane scouring by biogas and chemical cleaning). Therefore, as mentioned earlier, minimising filtration costs means decreasing $M L S S_{M T}$. Nevertheless, as Figure 5b shows, decreasing $M L S S_{M T}$ causes the cost of the biological process to climb, i.e. decreasing $M L S S_{M T}$ (at a given $J_{20}$ and $R_{\text {rec }}$ ) means reducing the MLSS concentration entering the membrane tank, which therefore requires larger reactor volumes.

Figure $5 \mathrm{~b}$ shows the optimum $M L S S_{M T}$ level giving the lowest AnMBR WWTP costs taking into account (i) no methane capture and (ii) energy recovered from methane (biogas methane and methane dissolved in the effluent). As this figure shows, also illustrated in Figure 5a, negligible energy is recovered from methane when sulphate-rich municipal wastewater is treated at low temperatures and SRTs below 45 days (mainly due to low hydrolysis rates), which did not offset the cost of the technology considered for recovering energy from methane (degassing membranes and CHP). Nonetheless, the optimum operating $M L S S_{M T}$ was $16 \mathrm{~g} \cdot \mathrm{L}^{-1}$ in both instances, i.e. $J_{20}=18 \mathrm{LMH}, R_{\text {rec }}=$ 3.2, and HRT $=17$ hours.

Table 2a summarises the optimum design values when treating sulphate-rich municipal wastewater in winter conditions. Table A.3 illustrates the main performance values experimentally obtained in the AnMBR plant in winter conditions versus the corresponding simulation results at the optimum design values. As this table shows, the experimental results are in accordance with the simulation results.

The resulting minimum AnMBR total costs were $€ 0.104$ and $€ 0.106$ per $\mathrm{m}^{3}$ of 
treated water taking into account (i) no methane capture and (ii) energy recovered from methane (biogas methane and methane dissolved in the effluent), respectively. The net energy consumption in winter conditions was 0.23 and $0.20 \mathrm{kWh}$ per $\mathrm{m}^{3}$, respectively.

\subsection{Optimum operating strategy in summer conditions}

Once the AnMBR WWTP had been designed for winter conditions (worst-case scenario), it was possible to determine the optimum operating strategy for summer conditions (best-case scenario). Figure 6 shows the effect of (a) SRT and (b) $R_{r e c}$ on the operating and maintenance costs in summer conditions taking into account (i) no methane capture and (ii) energy recovered from methane. As Figure 6a illustrates, the operating and maintenance costs are considerably lower when the methane is captured for energy recovery. Indeed, the average methane production when treating sulphaterich municipal wastewater in summer conditions (operating at $30^{\circ} \mathrm{C}$ ) was enough to offset the cost of the technology considered for recovering energy from methane (degassing membranes and CHP). In addition, increasing the SRT in summer conditions increases the amount of methane produced considerably (see Figure 3a), resulting in lower operating costs. However, increasing the SRT for a given $R_{\mathrm{rec}}$ also increases the $M L S S_{M T}$, resulting in higher filtration operating and maintenance costs. Therefore, in summer conditions, the SRTs must be optimised in order to minimise operating and maintenance costs in AnMBR technology. In this study, the optimum SRT in summer conditions resulted in 27 days when methane was captured from both biogas and permeate.

However, since the volume of the anaerobic reactor depends on the winter design and the SRT is optimised in order to maximise methane production, it is only possible to optimise the $M L S S_{M T}$ in summer conditions by modifying $R_{\text {rec. }}$ As Figure $6 \mathrm{~b}$ illustrates, 
operating and maintenance costs can be minimised by optimising $R_{\text {rec }}$, which indirectly optimises $M L S S_{M T}$. Specifically, a decrease in $R_{\text {rec }}$ causes $M L S S_{M T}$ to increase, leading to higher operating and maintenance costs related mainly to membrane scouring by biogas, chemical cleaning and membrane replacement. On the other hand, an increase in $R_{\text {rec }}$ causes $M L S S_{M T}$ to fall but increases the cost of pumping sludge. Finally, the optimum summer $R_{\text {rec }}$ was 1.8 which resulted in an $M L S S_{M T}$ of approx. $12 \mathrm{~g} \cdot \mathrm{L}^{-1}$, i.e. an optimum operating $J_{20}$ of $21 \mathrm{LMH}$.

Table 2a shows the optimal values for the operating parameters evaluated in this study when treating sulphate-rich municipal wastewater in summer conditions. Table A.3 also illustrates the main performance values experimentally obtained in the AnMBR plant in summer conditions versus the corresponding simulation results at the optimum design values. Also for this scenario, the experimental results are in accordance with the simulation results.

The resulting optimum operating and maintenance costs were $€ 0.099$ and $€ 0.089$ per $\mathrm{m}^{3}$ of treated water when (i) no energy was recovered from methane and (ii) energy was recovered from methane. The net energy consumption in summer conditions was 0.21 and $0.08 \mathrm{kWh}$ per $\mathrm{m}^{3}$, respectively.

\subsection{Effect of sulphate levels in influent on AnMBR total cost}

Following the methodology proposed in this paper, Table $2 \mathrm{~b}$ summarises the optimum design and operating values when treating low-sulphate municipal wastewater in winter and summer conditions, respectively.

Table 3 gives the total annual cost of the proposed AnMBR WWTP and its energy 
requirements when treating sulphate-rich and low-sulphate municipal wastewater. Table 3 shows that the total cost of an AnMBR WWTP is significantly lower when treating low-sulphate rather than sulphate-rich municipal wastewater (cost savings of up to $28 \%$ were estimated in this study). This demonstrates that, thanks to its very low costs, AnMBR technology is more feasible for treating low/non sulphate-loaded wastewaters.

It must also be said that AnMBR technology has the potential to be a net energy producer when treating low-sulphate municipal wastewater. Table 3 shows that when methane is captured from both biogas and effluent, it is possible to obtain surplus energy that can be utilised and/or sold, giving a maximum theoretical energy production of $0.07 \mathrm{kWh}$ per $\mathrm{m}^{3}$.

In comparison with other existing technologies for municipal wastewater treatment, for instance, Judd and Judd [6] reported that the full-scale aerobic MBR from Peoria (USA) has a membrane and total aeration energy demand of around 0.34 and $0.55 \mathrm{kWh}$ per $\mathrm{m}^{3}$. This energy demand is low compared to the consumption of other full-scale municipal aerobic MBRs. With regard to conventional activated sludge systems, Schilde (Belgium) WWTP consumed $0.19 \mathrm{kWh}$ per $\mathrm{m}^{3}$ [30]. Therefore, from an energy perspective, AnMBR is a promising sustainable system compared to other existing municipal wastewater treatment technologies. However, it is important to consider that the energy demand from the AnMBR system evaluated in this study does not take into account the energy needed for nutrient removal, which is considered in the wastewater treatment plants that has been mentioned as references.

\section{Conclusions}

The proposed methodology was used to design an AnMBR WWTP treating sulphate- 
rich and low-sulphate municipal wastewater at 15 and $30^{\circ} \mathrm{C}$. The total annual cost of the proposed AnMBR WWTP when treating sulphate-rich municipal wastewater was $€ 0.101$ and $€ 0.097$ per $\mathrm{m}^{3}$ of treated water when (i) no energy was recovered from methane and (ii) energy was recovered from methane (biogas methane and methane dissolved in the effluent), respectively. The total cost when treating low-sulphate municipal wastewater resulted in $€ 0.097$ and $€ 0.070$ per $\mathrm{m}^{3}$ of treated water for the two aforementioned scenarios, respectively. These results demonstrate that AnMBR is a feasible technology for treating low/non sulphate-loaded wastewater.

\section{Acknowledgements}

This research work was possible thanks to projects CTM2011-28595-C02-01/02 (funded by the Spanish Ministry of Economy and Competitiveness jointly with the European Regional Development Fund and Generalitat Valenciana GVAACOMP2013/203) and FCC Aqualia INNPRONTA IISIS IPT-20111023 (partially funded by the CDTI (Centre for Industrial Technological Development) and supported by the Spanish Ministry of Economy and Competitiveness).

\section{References}

[1] B. Lew, S. Tarre, M. Beliavski, C. Dosoretz, M. Green, Anaerobic membrane bioreactor (AnMBR) for domestic wastewater treatment, Desalination 243 (2009) 251-257.

[2] G. Lettinga, S. Rebac, G. Zeeman, Challenge of psychrophilic anaerobic wastewater treatment, Trends Biotechnol. 19 (2001) 363-370.

[3] D. Jeison, Anaerobic membrane bioreactor for wastewater treatment: Feasibility and potential applications, PhD thesis, Wageningen University, Wageningen, The Netherlands, 2007.

[4] R. Pretel, A. Robles M.V. Ruano, A. Seco, J. Ferrer, The operating cost of an anaerobic membrane bioreactor (AnMBR) treating sulphate-rich urban wastewater, Sep. Purif. Technol. 126 (2014) 30 - 38.

[5] S. Judd, The status of membrane bioreactor technology, Trends Biotechnol. 26 (2008) 109 - 116. 
[6] S.J. Judd, C. Judd, Principles and Applications of Membrane Bioreactors, in: Water and Wastewater Treatment, Second Edition. Elsevier, London, UK, 2011.

[7] A. Drews, Membrane fouling in membrane bioreactors - Characterization, contradictions, causes and cures, J Membrane Sci. 253 (2010) $1-28$.

[8] S.I. Patsios, A.J. Karabelas, An investigation of the long-term filtration performance of a membrane bioreactor (MBR): The role of specific organic fractions, J. Membrane Sci. 253(2011) 102 - 115.

[9] A. Robles, M.V. Ruano, J. Ribes, J. Ferrer, Factors that affect the permeability of commercial hollowfibre membranes in a submerged anaerobic MBR (HF-SAnMBR) system, Water Res. 47 (2013a) 12771288.

[10] A. Robles, M.V Ruano, J. Ribes, A. Seco, J. Ferrer, Model-based automatic tuning of a filtration control system for submerged anaerobic membrane bioreactors (AnMBR), J. Membrane Sci. 465 (2014) $14-26$.

[11] R.W. Field, D. Wu, J.A. Howell, B.B. Gupta, Critical flux concept for microfiltration fouling, J. Membrane Sci. 100 (1995) 259 - 272.

[12] B. Verrecht, T. Maere, I. Nopens, C. Brepols, S. Judd, The cost of a large-scale hollow fibre MBR, Water Res. 44 (2010) $5274-5283$.

[13] H. Ozgun, R.K. Dereli, M.E. Ersahin, C. Kinaci, H. Spanjers, J.B. van Lier, A review of anaerobic membrane bioreactors for municipal wastewater treatment: Integration options, limitations and expectations, Sep. Purif. Technol. 118 (2012) 89-104.

[14] L.M. Raskin, Anaerobic Membrane Bioreactors for Sustainable Wastewater Treatment. WERF Report U4R08, 2012.

[15] A.L. Smith, L.B. Stadler, N.G. Love, S.J. Skerlos, L. Raskin, Perspectives on anaerobic membrane bioreactor treatment of domestic wastewater: A critical review, Bioresource Technol. 122 (2012) 149-159. [16] D.C. Stuckey, Recent developments in anaerobic membrane reactors, Bioresource Technol. 122 (2012) $137-148$.

[17] H. Lin, W. Peng, M. Zhang, J. Chen, H. Huachang, Y. Zhang, A review on anaerobic membrane bioreactors: Applications, membrane fouling and future perspectives, Desalination 314 (2013) 169-188.

[18] J. Ferrer, A. Seco, J. Serralta, J. Ribes, J. Manga, E. Asensi, J.J. Morenilla , F. Llavador, DESASS: A software tool for design, simulating and optimising WWTPs, Environ. Modell. Softw. 23 (2008) 19-26. [19] J.B. Giménez, A. Robles, L. Carretero, F. Durán, M.V. Ruano, M.N. Gatti, J. Ribes, J. Ferrer, A. Seco, Experimental study of the anaerobic urban wastewater treatment in a submerged hollow-fibre membrane 
bioreactor at pilot scale. Bioresource Technol. 102 (2011) 8799 - 8806.[20] APHA. Standard Methods for the Examination of Water and Wastewater, 21st edition. American Public Health Association/American Water Works Association/Water Environmental Federation, Washington DC, USA, 2005.

[21] WRC, Simple titration procedures to determine $\mathrm{H} 2 \mathrm{CO} 3 *$ alkalinity and short-chain fatty acids in aqueous solutions containing known concentrations of ammonium, phosphate and sulphide weak acid/bases, Report No. TT 57/92, Water Research Commission, University of Cape Town, Pretoria, Republic of South Africa, 1992.

[22] R. Barat, J. Serralta, M.V. Ruano, E. Jiménez, J. Ribes, A. Seco, J. Ferrer, Biological nutrient removal model No 2 (BNRM2): a general model for wastewater treatment plants, Water Sci. Technol. 67 (2013) 1481-1489.

[23] F. Durán, Mathematical modelling of the anaerobic urban wastewater treatment including sulphatereducing bacteria. Application to an anaerobic membrane bioreactor (Modelación matemática del tratamiento anaerobio de aguas residuales urbanas incluyendo las bacterias sulfatorreductoras, Aplicación a un biorreactor anaerobio de membranas), Ph.D. thesis, Dept. of Hydraulic Engineering and Environment, Universitat Politècnica de València, Spain, 2013.

[24] A. Robles, M.V. Ruano, J. Ribes, J. Ferrer, Performance of industrial scale hollow-fibre membranes in a submerged anaerobic MBR (HF-SAnMBR) system at mesophilic and psychrophilic conditions, Sep. Purif. Technol. 104 (2013) 290-296.

[25] M. Molinos-Senante, F. Hernández-Sancho, R. Sala-Garrido, M .Garrido-Baserba, Economic feasibility study for wastewater treatment: a cost-benefit analysis. Sci. Total Environ. 408 (2011), 953-957. [26] R. Pretel, A. Robles M.V. Ruano, A. Seco, J. Ferrer, Environmental impact of submerged anaerobic MBR (AnMBR) technology used to treat urban wastewater at different temperatures, Bioresource Technol. 149 (2013) $532-540$.

[27] EPA, Environmental Protection Agency, Combined Heat and Power Partnership, Agency of the United States Federal Government, 2012.

[28] A. Robles, M.V Ruano, J. Ribes, J. Ferrer, Sub-critical long-term operation of industrial scale hollowfibre membranes in a submerged anaerobic MBR (HF-SAnMBR) system, Sep Purif Technol. 100 (2012) 88-96.

[29] X. Elias-Castell, Routes of treatment and recovery of sewage sludge (Vías de tratamiento y valorización de fangos de depuradora), Ediciones Díaz de Santos, Madrid, Spain, 2012.

[30] Fenu, J. Roels, T.Wambecq, K. De Gussem, C. Thoeye, G. De Gueldre, B. Vand De Steene, Energy 
audit of a full scaleMBR system, Desalination, 262 (2010) 121-128.

[31] Bank BEDEC - ITeC database, In Construmatica, Available on http://www.construmatica.com/bedec, (accessed 1 february 2013).

[32] Iberdrola S.A., Spanish electricity tariff (Tarifa eléctrica España). In Iberdrola. Available on https://www.iberdrola.es/clientes/empresas/info/mercado-energetico, (accessed 5 march 2013).

[33] J.A. Sainz-Lastre, Technologies for sustainability, Processes and unit operations in wastewater treatment (Tecnologías para la sostenibilidad, Procesos y operaciones unitarias en depuración de aguas residuales), Colección EOI Medio Ambiente, Madrid, Spain, 2005.

[34] Miliarium Aureum, S.L, Approximate cost of WWTP (Coste estimativo EDAR), In Miliarium.com Ingeniería Civil $\quad \mathrm{y} \quad$ Medio $\quad$ Ambiente, $\quad$ Available http://www.miliarium.com/Proyectos/Depuradoras/introduccion/edar.asp, (accessed 20 april 2013).

[35] Bombas Ideal S.A., Distribution Catalogue (Catálogo Distribución), In Bombas Ideal, Available on http://www.bombas-ideal.com/pdf/CAT\%20C9\%20ES\%20\%5BD-100512\%5D.pdf, (accessed 5 march 2013).

[36] MAGRAMA. Official website of the Ministry of Agriculture, Food and Environment. Spanish government, Madrid. Survey land prices 2012. Available $\quad$ on http://www.magrama.gob.es/es/estadistica/temas/estadisticas, $\quad$ (accessed $\quad 5 \quad$ may 2014 ). agrarias/Encuesta_Precios_Tierra_2012 tcm7-298705.pdf

\section{Table and figure captions}

Table 1. Impact of design parameters on cost of (a) biological process and (b) filtration.

Table 2. Optimum design values using the operating variables evaluated in this case study when treating 
(a) sulphate-rich municipal wastewater and (b) low-sulphate municipal wastewater. $* J_{20}$ values based on the experimentally-determined critical flux in the AnMBR plant [24].

Table 3. Optimum cost and energy requirements of the proposed AnMBR WWTP when treating sulphate-rich and low-sulphate municipal wastewater.

Figure 1. Process flow diagram for the proposed AnMBR WWTP (CIP: clean-in-place; HE: heat exchanger; CHP: combined heat and power).

Figure 2. Correlation between the sludge recycling ratio $\left(R_{\mathrm{rec}}=\right.$ sludge recycling flow from the membrane tank to the anaerobic reactor per influent flow) and the ratio between the reactor volume $(V)$ and the reference reactor volume obtained for $R_{r e c}=1\left(V^{\prime}\right)$.

Figure 3. Simulation results. Influence of SRT on: (a) methane present in biogas stream at $15^{\circ} \mathrm{C}(\boldsymbol{C})$ and $30^{\circ} \mathrm{C}($ - _- $)$, and percentage of BVSS in the mixed liquor at $15^{\circ} \mathrm{C}(\leftrightharpoons)$ and $30^{\circ} \mathrm{C}\left({ }_{-}\right)$; and (b) effluent $\mathrm{COD}$ (not including methane dissolved in effluent) at $15^{\circ} \mathrm{C}\left(\longleftarrow\right.$ ) and $30^{\circ} \mathrm{C}(--\mathbf{- n})$, and effluent BOD (not including methane dissolved in effluent) at $15^{\circ} \mathrm{C}$ (

Figure 4. Optimum AnMBR design in winter conditions at different $M L S S_{M T}$ levels. (a) Effect of $\mathbf{J}_{20}$ on filtration cost at $M L S S_{M T}$ of 5, 10,15, 20 and $25 \mathrm{~g} \cdot \mathrm{L}^{-1}$. (b) Contribution to filtration cost by membrane scouring using biogas; chemicals consumed; and membrane size at $M L S S_{M T}$ of 5, 10, 15, 20 and $25 \mathrm{~g} \cdot \mathrm{L}^{-1}$. Figure 5. Optimum AnMBR design in winter conditions $\left(T=15^{\circ} \mathrm{C}\right)$. Effect on AnMBR cost of: (a) SRT; and (b) $M L S S_{M T}$. Cost of biological process (__-_ $)$; cost of filtration ( $(-$ ); total cost without energy recovery (_ — $)$; and total cost including energy recovery from methane ( - ).

Figure 6. Optimum AnMBR operating strategy in summer conditions $\left(\mathrm{T}=30^{\circ} \mathrm{C}\right)$. Effect on AnMBR cost of: (a) SRT; and (b) sludge recycling ratio $\left(R_{\mathrm{rec}}=\right.$ sludge recycling flow from the membrane tank to the anaerobic reactor / influent flow). Operating cost without energy recovery ( _ _ $)$; and operating cost including energy recovery from methane ( $)$.

\section{Appendix A: supplementary information}

Table A.1. Characteristics of the wastewater entering the anaerobic reactor used for designing the 
proposed AnMBR WWTP ( ${ }^{*}$ sulphate-rich municipal wastewater; ${ }^{* *}$ low-sulphate municipal wastewater).

Table A.2. Unit costs used to evaluate capital and operating expenses (CAPEX/OPEX) in the proposed AnMBR WWTP scheme.

Figure A.1. Proposed design methodology for AnMBR technology.

Table 1. Impact of design parameters on cost of (a) biological process and (b) filtration. 


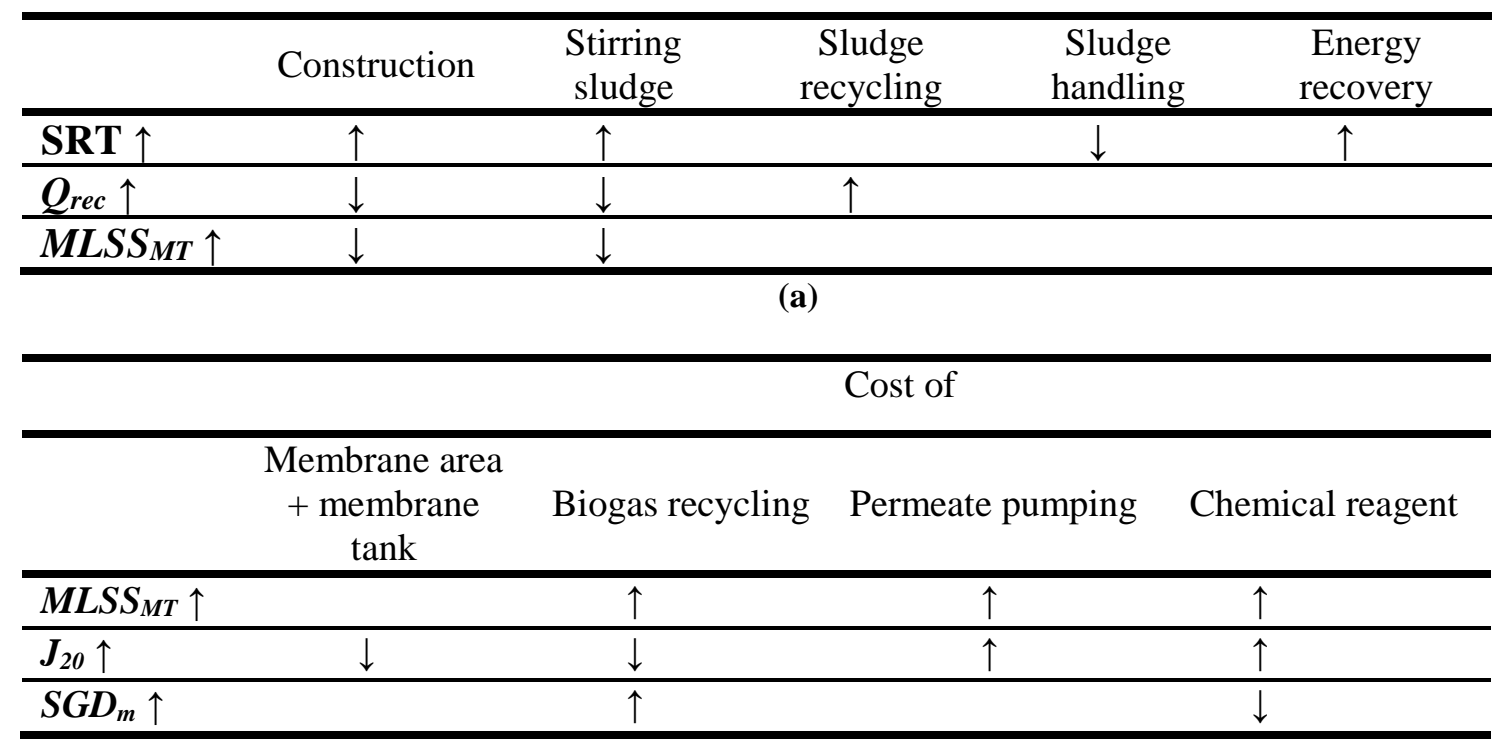

(b) 
Table 2. Optimum design values using the operating variables evaluated in this case study when treating (a) sulphate-rich municipal wastewater and (b) low-sulphate municipal wastewater. $* J_{20}$ values based on the experimentally-determined critical flux in the AnMBR plant [24].

\begin{tabular}{lcc}
\cline { 2 - 3 } & Winter $\left(\mathrm{T}=15^{\circ} \mathrm{C}\right)$ & Summer $\left(\mathrm{T}=30^{\circ} \mathrm{C}\right)$ \\
\hline SRT (days) & 35 & 27 \\
\hline HRT (hours) & 17 & 17 \\
\hline$R_{\text {rec }}$ & 3.2 & 1.8 \\
\hline$J_{20}(\mathrm{LMH}) *$ & 18 & 21 \\
\hline$M L S S_{M T}\left(\mathrm{~g} \cdot \mathrm{L}^{-1}\right)$ & 16 & 12 \\
\hline$T M P(\mathrm{bar})$ & 0.1 & 0.1 \\
\hline$S G D_{m}\left(\mathrm{~m}^{3} \cdot \mathrm{h}^{-1} \cdot \mathrm{m}^{-2}\right)$ & 0.1 & 0.1 \\
\hline
\end{tabular}

(a)

\begin{tabular}{lcc}
\cline { 2 - 3 } & Winter $\left(\mathrm{T}=15^{\circ} \mathrm{C}\right)$ & Summer $\left(\mathrm{T}=30^{\circ} \mathrm{C}\right)$ \\
\hline SRT (days) & 41 & 23 \\
\hline HRT (hours) & 17 & 17 \\
\hline$R_{\text {rec }}$ & 3.2 & 1.2 \\
\hline$J_{20}(\mathrm{LMH}) *$ & 18 & 21 \\
\hline$M L S S_{M T}\left(\mathrm{~g} \cdot \mathrm{L}^{-1}\right)$ & 15 & 12 \\
\hline$T M P(\mathrm{bar})$ & 0.1 & 0.1 \\
\hline$S G D_{m}\left(\mathrm{~m}^{3} \cdot \mathrm{h}^{-1} \cdot \mathrm{m}^{-2}\right)$ & 0.1 & 0.1 \\
\hline
\end{tabular}

(b) 
Table 3. Optimum cost and energy requirements of the proposed AnMBR WWTP when treating sulphate-rich and low-sulphate municipal wastewater.

\begin{tabular}{ccccc}
\cline { 2 - 5 } & \multicolumn{2}{c}{$\begin{array}{c}\text { Total AnMBR cost } \\
\left(€ \text { per } \mathrm{m}^{3}\right)\end{array}$} & $\begin{array}{c}\text { AnMBR energy requirements } \\
\left(\mathrm{kWh} \text { per } \mathrm{m}^{3}\right)\end{array}$ \\
\cline { 2 - 5 } & $\begin{array}{c}\text { Sulphate-rich } \\
\text { municipal } \\
\text { wastewater }\end{array}$ & $\begin{array}{c}\text { Low-sulphate } \\
\text { municipal } \\
\text { wastewater }\end{array}$ & $\begin{array}{c}\text { Sulphate-rich } \\
\text { municipal } \\
\text { wastewater }\end{array}$ & $\begin{array}{c}\text { Low-sulphate } \\
\text { municipal } \\
\text { wastewater }\end{array}$ \\
\hline No methane capture & 0.101 & 0.097 & 0.22 & 0.21 \\
\hline $\begin{array}{c}\text { Energy recovered from methane } \\
\text { (biogas methane and methane } \\
\text { dissolved in the effluent) }\end{array}$ & 0.097 & 0.070 & 0.14 & -0.07 \\
\hline
\end{tabular}




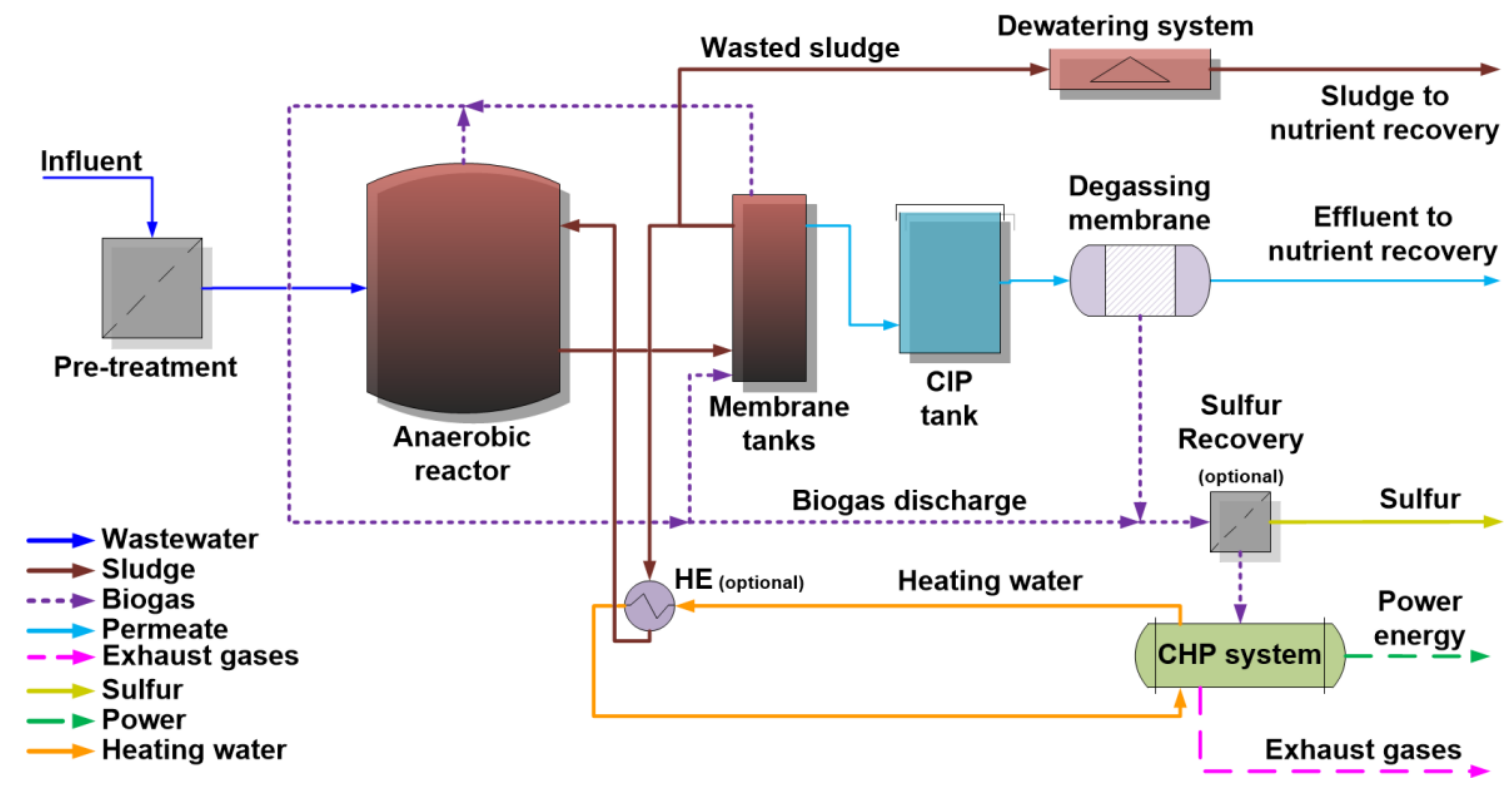

Figure 1. Process flow diagram for the proposed AnMBR WWTP (CIP: clean-in-place; HE: heat exchanger; CHP: combined heat and power). 


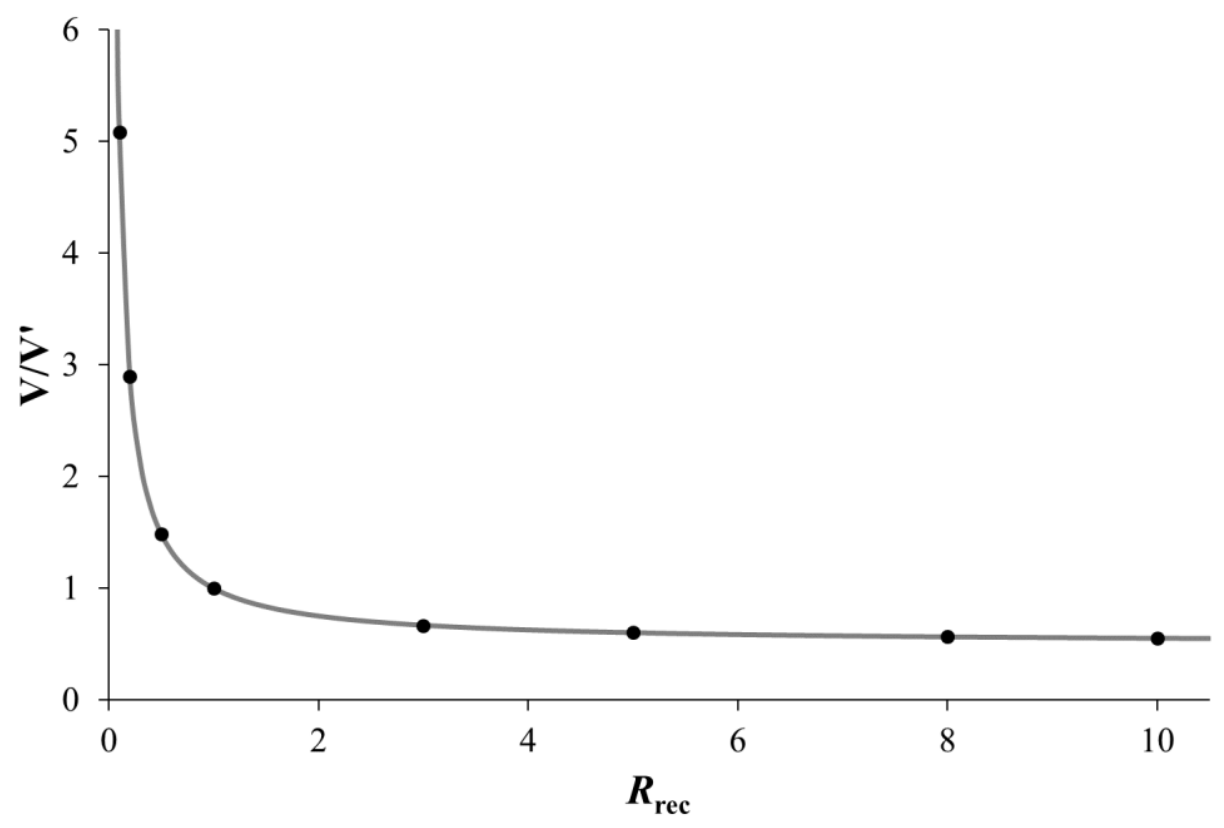

Figure 2. Correlation between the sludge recycling ratio $\left(R_{\mathrm{rec}}=\right.$ sludge recycling flow from the membrane tank to the anaerobic reactor per influent flow) and the ratio between the reactor volume $(V)$ and the reference reactor volume obtained for $R_{r e c}=1\left(V^{\prime}\right)$. 


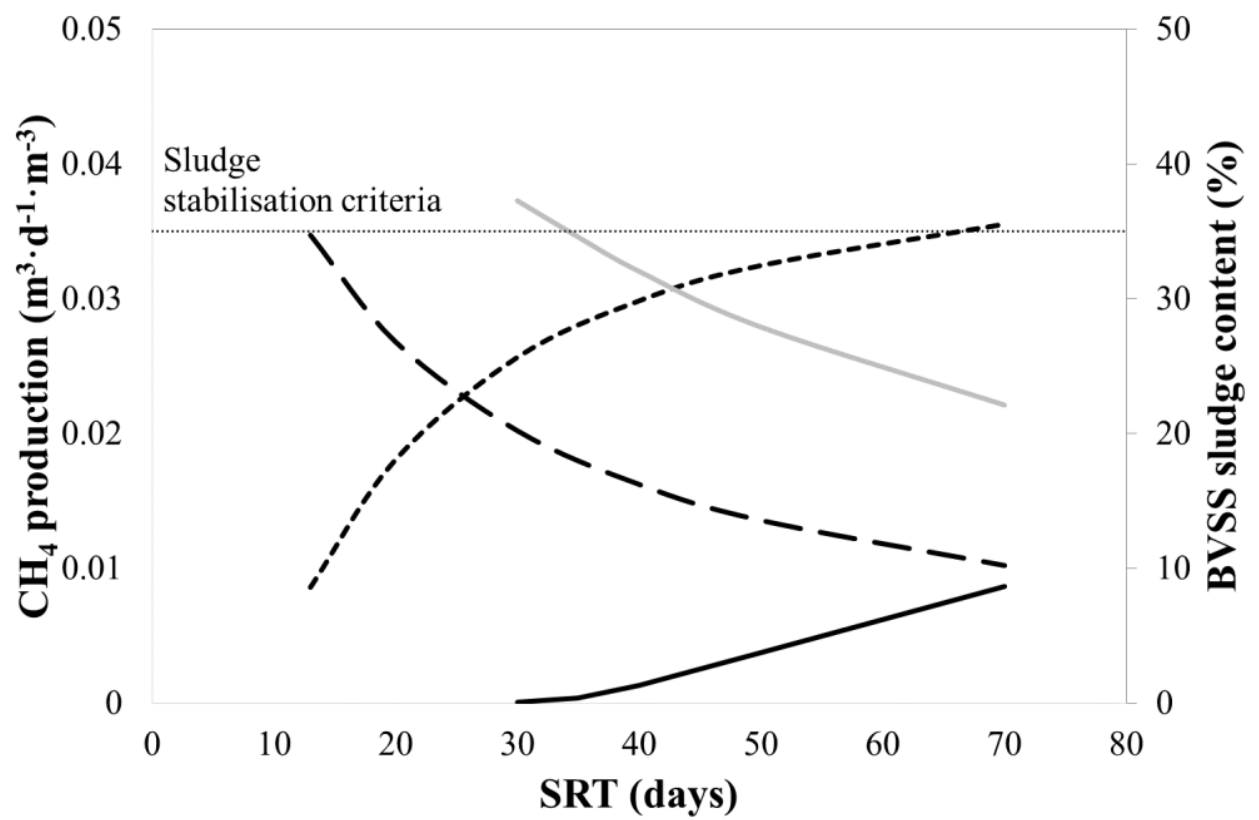

(a)

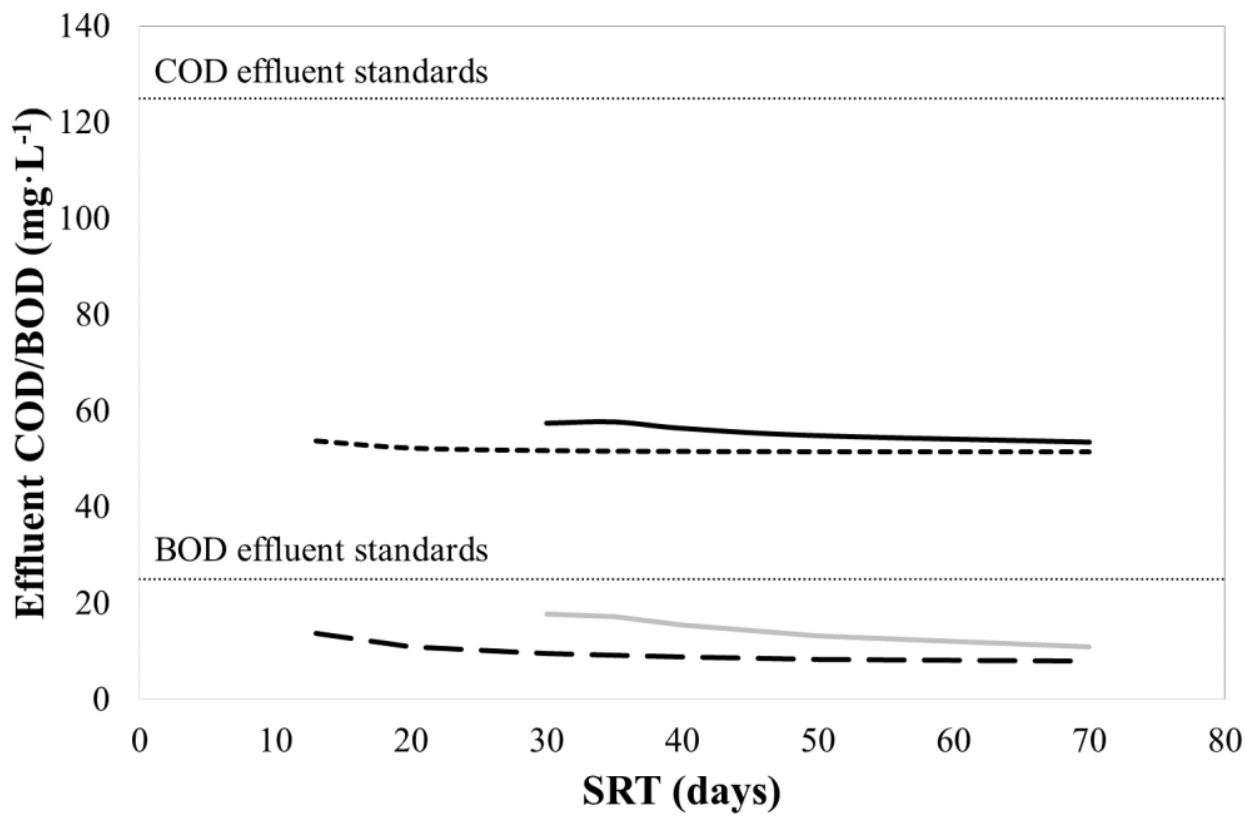

(b)

Figure 3. Simulation results. Influence of SRT on: (a) methane present in biogas stream at $15{ }^{\circ} \mathrm{C}(\boldsymbol{C})$ and $30^{\circ} \mathrm{C}(----)$, and percentage of BVSS in the mixed liquor at $15^{\circ} \mathrm{C}(\longrightarrow)$ and $30^{\circ} \mathrm{C}(--)$; and (b) effluent $\mathrm{COD}$ (not including methane dissolved in effluent) at $15^{\circ} \mathrm{C}(-)$ and $30^{\circ} \mathrm{C}(---\mathbf{-})$, and effluent BOD (not including methane dissolved in effluent) at $15^{\circ} \mathrm{C}(\longrightarrow)$ and $30^{\circ} \mathrm{C}(\boldsymbol{Z})$. 


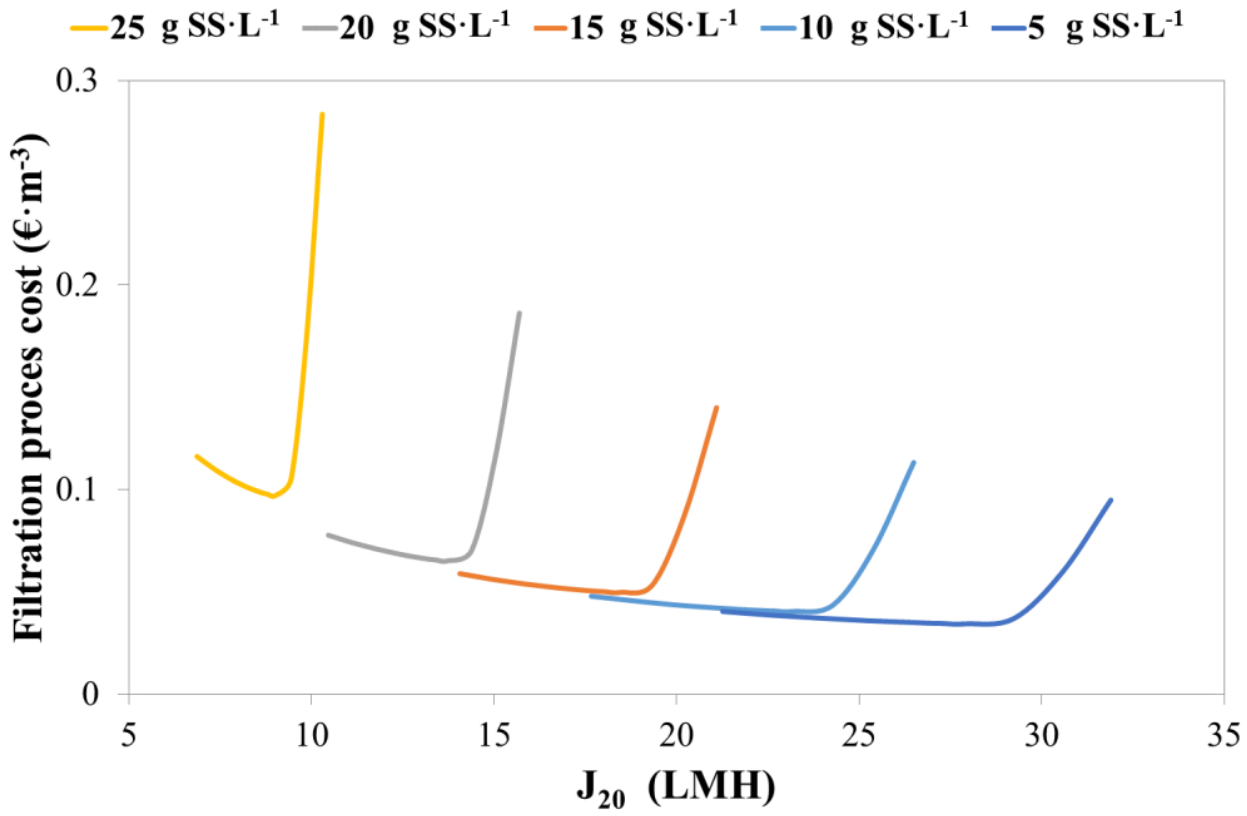

(a)

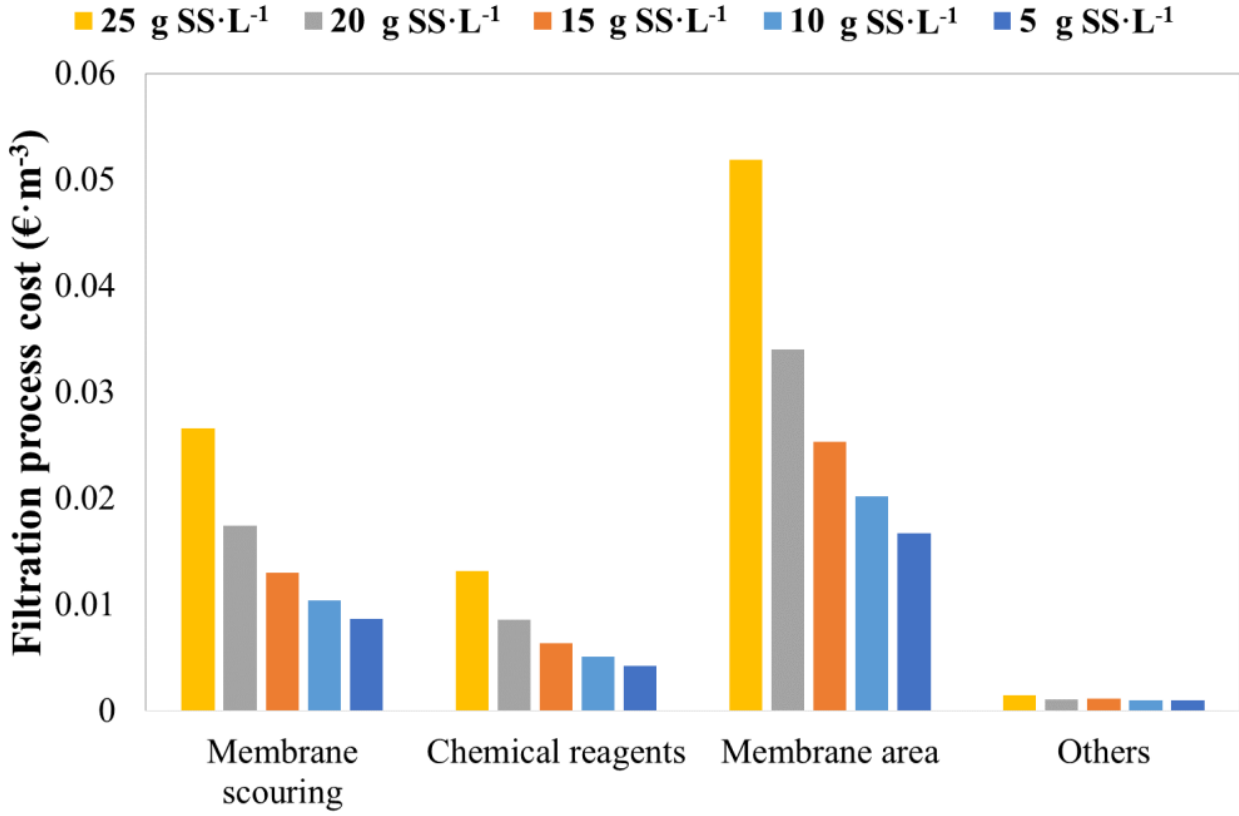

(b)

Figure 4. Optimum AnMBR design in winter conditions at different $M L S S_{M T}$ levels. (a) Effect of $\mathrm{J}_{20}$ on filtration cost at $M L S S_{M T}$ of 5,10,15, 20 and $25 \mathrm{~g} \cdot \mathrm{L}^{-1}$. (b) Contribution to filtration cost by membrane scouring using biogas; chemicals consumed; and membrane size at $M L S S_{M T}$ of 5, 10, 15, 20 and $25 \mathrm{~g} \cdot \mathrm{L}^{-1}$. 


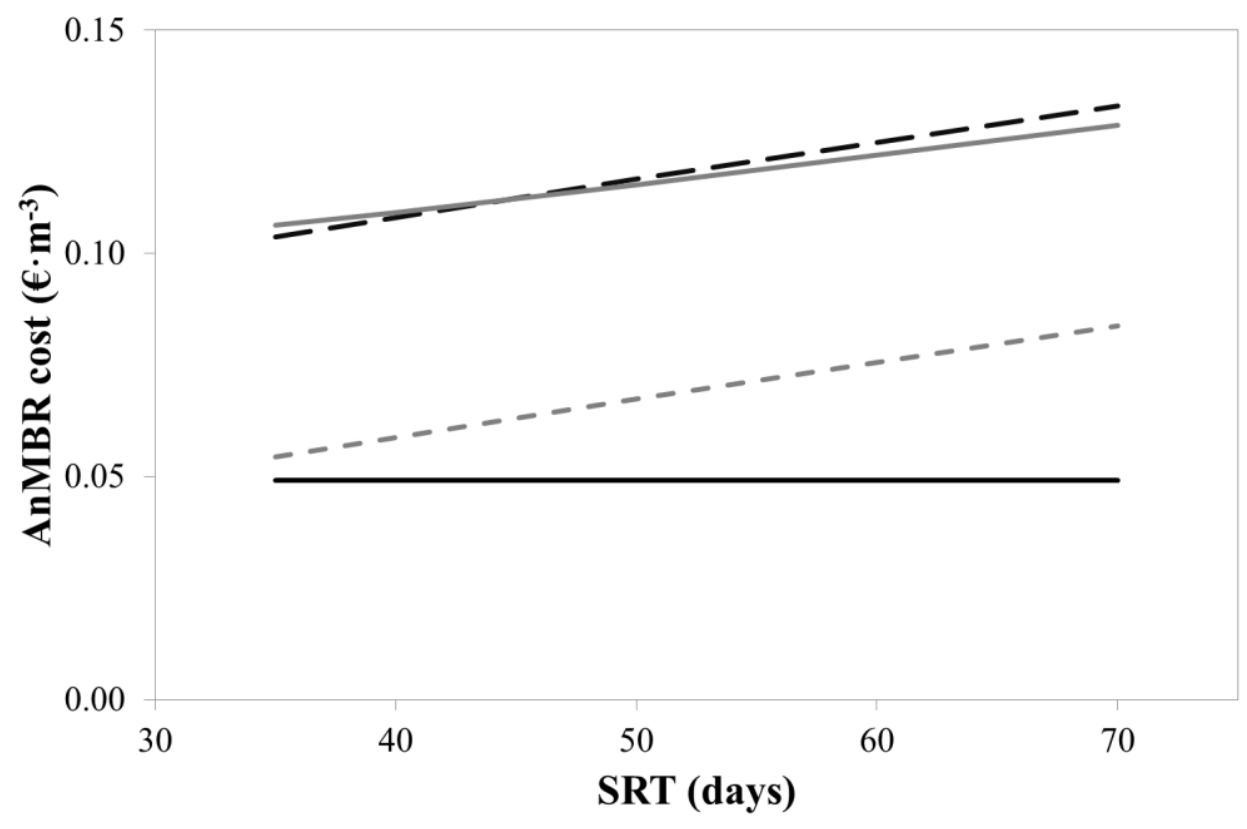

(a)

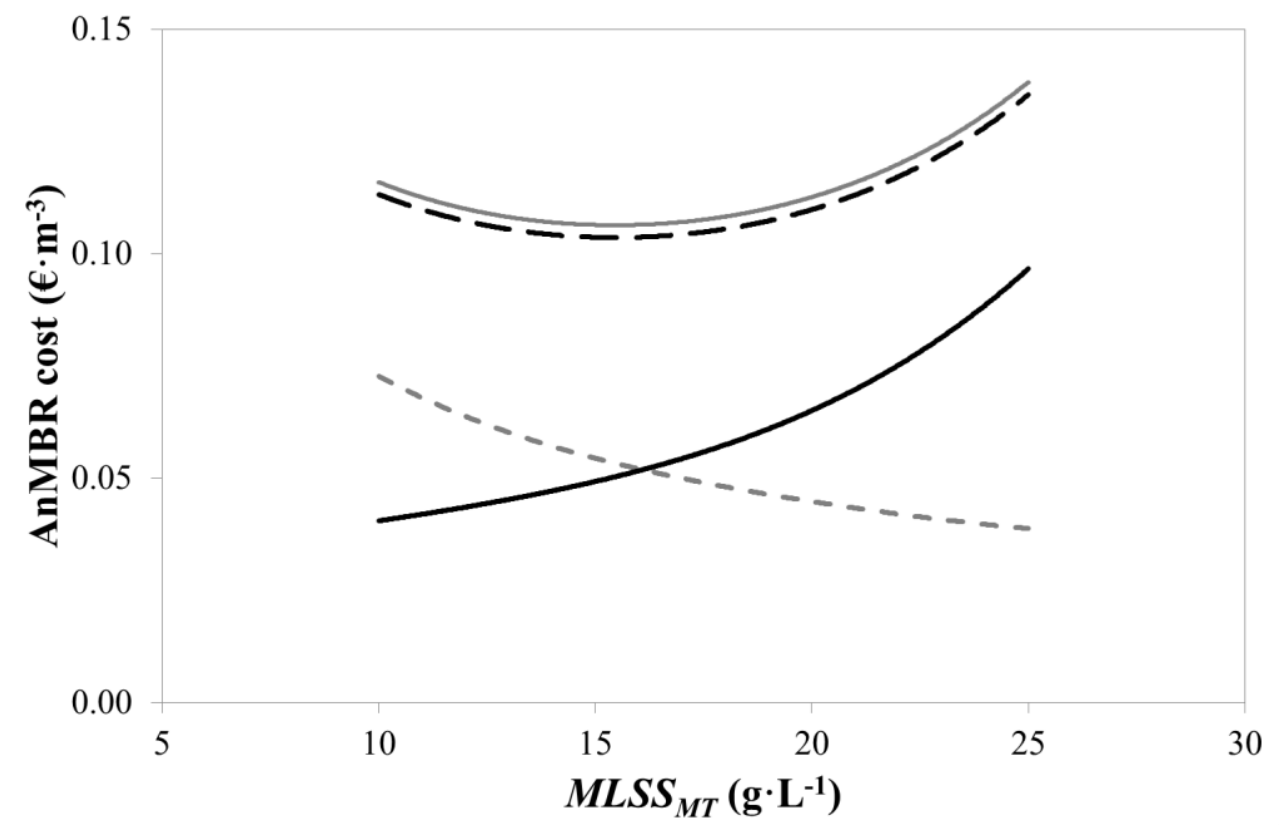

(b)

Figure 5. Optimum AnMBR design in winter conditions $\left(T=15^{\circ} \mathrm{C}\right)$. Effect on AnMBR cost of: (a) SRT; and (b) $M L S S_{M T}$. Cost of biological process (----); cost of filtration (_) ; total cost without energy recovery (_ — ); and total cost including energy recovery from methane (_ $)$. 


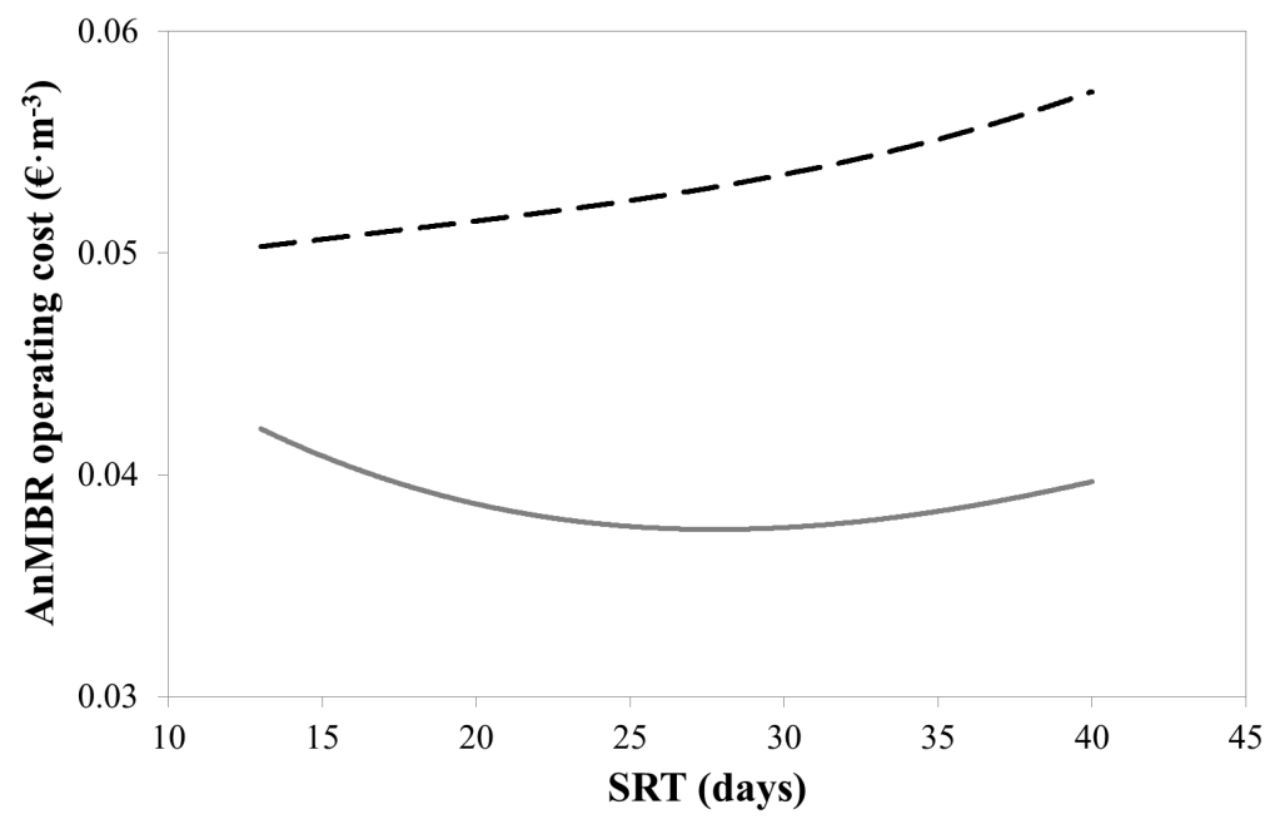

(a)

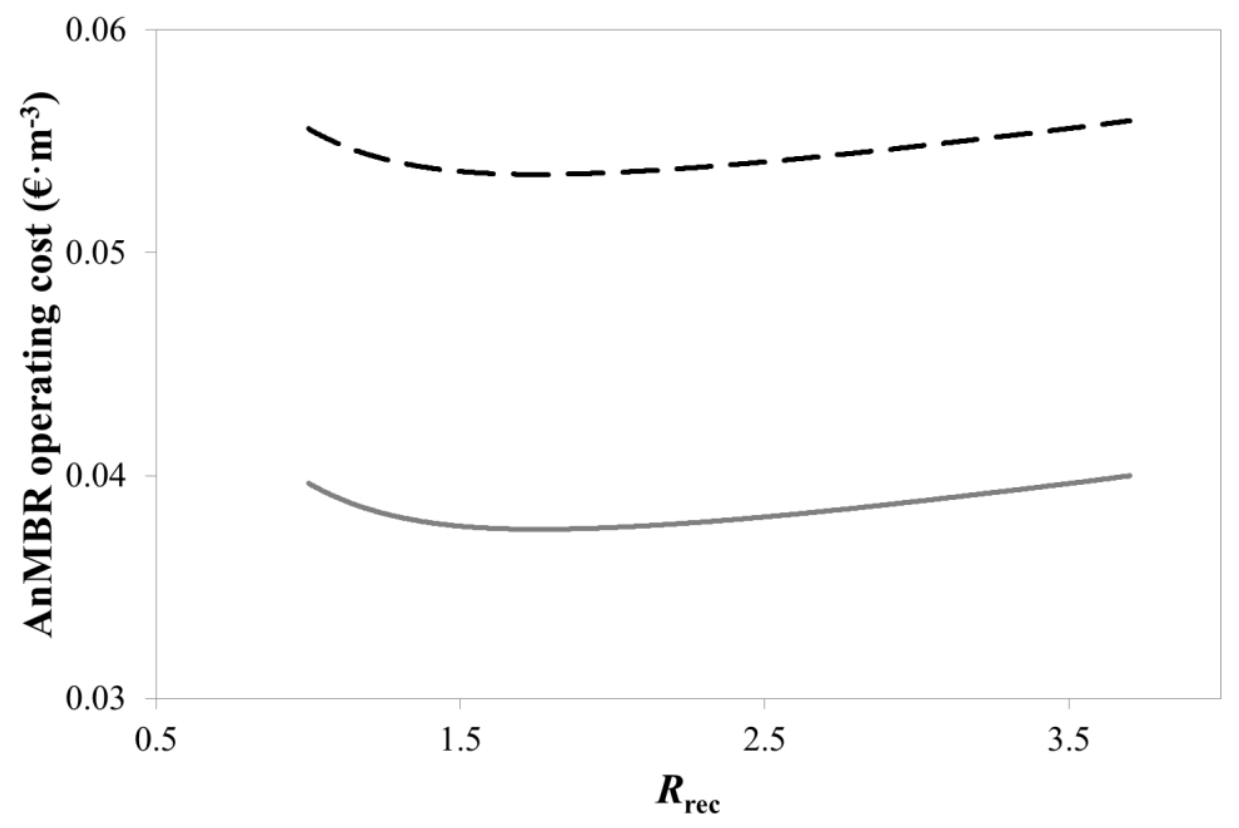

(b)

Figure 6. Optimum AnMBR operating strategy in summer conditions $\left(T=30^{\circ} \mathrm{C}\right)$. Effect on AnMBR cost of: (a) SRT; and (b) sludge recycling ratio $\left(R_{\mathrm{rec}}=\right.$ sludge recycling flow from the membrane tank to the anaerobic reactor / influent flow). Operating cost without energy recovery (_ - ); and operating cost including energy recovery from methane $(\square)$. 


\section{Appendix A: supplementary information}

Table A.1. Characteristics of the wastewater entering the anaerobic reactor used for designing the proposed AnMBR WWTP $\left({ }^{*}\right.$ sulphate-rich municipal wastewater; ${ }^{* *} l o w$-sulphate municipal wastewater $)$.

\begin{tabular}{|c|c|c|}
\hline Parameter & Unit & Value \\
\hline TSS & $\mathrm{mg}$ TSS $\cdot \mathrm{L}^{-1}$ & 315 \\
\hline VSS & $\mathrm{mg}$ VSS $\cdot \mathrm{L}^{-1}$ & 254 \\
\hline T-COD & $\mathrm{mg} \mathrm{COD} \cdot \mathrm{L}^{-1}$ & 568 \\
\hline S-COD & $\mathrm{mg}$ COD $\cdot \mathrm{L}^{-1}$ & 83 \\
\hline $\mathrm{T}-\mathrm{BOD}_{20}$ & $\mathrm{mg} \mathrm{COD} \cdot \mathrm{L}^{-1}$ & 363 \\
\hline $\mathrm{S}-\mathrm{BOD}_{20}$ & $\mathrm{mg} \mathrm{COD} \cdot \mathrm{L}^{-1}$ & 64 \\
\hline VFA & $\mathrm{mg} \mathrm{COD} \cdot \mathrm{L}^{-1}$ & 8 \\
\hline $\mathrm{SO}_{4}-\mathrm{S}$ & $\mathrm{mg} \mathrm{S} \cdot \mathrm{L}^{-1}$ & $100 * / 10^{* *}$ \\
\hline $\mathrm{TN}$ & $\mathrm{mg} \mathrm{N} \cdot \mathrm{L}^{-1}$ & 55 \\
\hline $\mathrm{NH}_{4}-\mathrm{N}$ & $\mathrm{mg} \mathrm{N} \cdot \mathrm{L}^{-1}$ & 33 \\
\hline $\mathrm{TP}$ & $\mathrm{mg} \mathrm{P} \cdot \mathrm{L}^{-1}$ & 10.3 \\
\hline $\mathrm{PO}_{4}-\mathrm{P}$ & $\mathrm{mg} \mathrm{P} \cdot \mathrm{L}^{-1}$ & 4.1 \\
\hline Alk & $\mathrm{mg} \mathrm{CaCO}{ }_{3} \cdot \mathrm{L}^{-1}$ & 337 \\
\hline $\mathrm{pH}$ & & 7.7 \\
\hline
\end{tabular}


Table A.2. Unit costs used to evaluate capital and operating expenses (CAPEX/OPEX) in the proposed AnMBR WWTP scheme.

\begin{tabular}{|c|c|c|}
\hline Unit costs of capital and operating expenses & & Reference \\
\hline Steel pipe (DN: $0.4 \mathrm{~m}) /(\mathrm{DN}: 1.4 \mathrm{~m}), € \cdot \mathrm{m}^{-1}$ & $115 / 520$ & [31] \\
\hline Concrete wall/slab, $€ \cdot \mathrm{m}^{-1}$ & $350 / 130$ & [31] \\
\hline $\begin{array}{l}\text { Ultrafiltration hollow-fibre membrane }(500,000 \mathrm{ppm} \cdot \mathrm{h} \\
\text { cumulative }), € \text { per } \mathrm{m}^{2}\end{array}$ & 35 & $\begin{array}{l}\text { PURON }^{\circledR}, \text { Koch } \\
\text { Membrane Systems }\end{array}$ \\
\hline Energy, $€$ per kWh & 0.138 & {$[32]$} \\
\hline $\begin{array}{l}\text { Sodium hypochlorite, ( } \mathrm{NaOCl} \mathrm{Cl} \text { active } 5 \% \text { PRS-CODEX), } \\
€ \cdot \mathrm{L}^{-1}\end{array}$ & 11 & Didaciencia S.A. \\
\hline Acid citric (Acid citric 1-hidrate PRS-CODEX), $€ \cdot t^{-1}$ & 23600 & Didaciencia S.A. \\
\hline Polyelectrolyte, $€ \cdot \mathrm{kg}^{-1}$ & 2.35 & [33] \\
\hline Residual sludge for farming, $€ \cdot \mathrm{t}^{-1}$ & 4.81 & [34] \\
\hline $\begin{array}{l}\text { Blower (ELEKTROR RD 84, } \mathrm{Q}_{\mathrm{B}}=5400 \mathrm{~m}^{3} \cdot \mathrm{h}^{-1} \text {; Lifetime: } \\
50000 \text { hours }), €\end{array}$ & 5900 & Elektror S.A. \\
\hline $\begin{array}{l}\text { Sludge recycling pump (ARS200-34CI/35CR, } \mathrm{Q}_{\mathrm{P}}=500 \\
\left.\mathrm{~m}^{3} \cdot \mathrm{h}^{-1} ; \text { Lifetime: } 65000 \text { hours }\right), €\end{array}$ & 25000 & {$[35]$} \\
\hline $\begin{array}{l}\text { Submersible stirrer (AGS } 400-3 \mathrm{SHG} / 6.1 \text {; Lifetime: } 100000 \\
\text { hours; } 3.4 \mathrm{~kW} \text {; anaerobic reactor }=5 \mathrm{~W} \cdot \mathrm{m}^{-3} \text {; anoxic reactor }=15 \\
\left.\mathrm{~W} \cdot \mathrm{m}^{-3}\right), €\end{array}$ & 11699 & {$[35]$} \\
\hline $\begin{array}{l}\text { Rotofilter (PAM 630/2000; pitch diameter }=0.5 \mathrm{~mm} ; \mathrm{Q}=320 \\
\left.\mathrm{~m}^{3} \cdot \mathrm{h}^{-1} ; \text { Lifetime: } 87600 \text { hours, } 11.45 \mathrm{~kW}\right), €\end{array}$ & 7796 & $\begin{array}{l}\text { Procesos Auto- } \\
\text { Mecanizados S.L }\end{array}$ \\
\hline $\begin{array}{l}\text { Microturbine-based CHP system (size: } 30 \mathrm{~kW} \text { ), capital cost, } \\
€ / \mathrm{kW} \text { and O\&M cost, } € / \mathrm{kWh} \text { (applying an exchange rate of: } \\
0.729 € / \$)\end{array}$ & $1968 / 0.015$ & {$[27]$} \\
\hline $\begin{array}{l}\text { Degassing membrane, }\left(\text { flow rate }=30 \mathrm{~m}^{3} \cdot \mathrm{h}^{-1} ; \text { pressure drop }=\right. \\
60 \mathrm{kPa}), \text { Capital cost, } €\end{array}$ & 7300 & DIC Corporation \\
\hline Land cost,$€ \cdot \mathrm{m}^{-2}$ & 0.97 & [36] \\
\hline
\end{tabular}


Table A.3. Average performance values experimentally obtained in the AnMBR plant versus the corresponding simulation results (data in brackets) obtained for the optimum design values in winter and summer conditions.

\begin{tabular}{lcc}
\hline & Winter & Summer \\
\hline Methane production $\left(\mathrm{m}^{3} \cdot \mathrm{d}^{-1} \cdot \mathrm{m}^{-3}\right)$ & $0.001(0.006)$ & $0.025(0.022)$ \\
\hline Effluent COD $\left(\mathrm{mg} \mathrm{COD} \cdot \mathrm{L}^{-1}\right)$ & $58.1(57.8)$ & $51.9(55.7)$ \\
\hline Membrane tank COD $\left(\mathrm{g} \mathrm{COD} \cdot \mathrm{L}^{-1}\right)$ & $7.6(8.1)$ & $8.7(8.3)$ \\
\hline
\end{tabular}




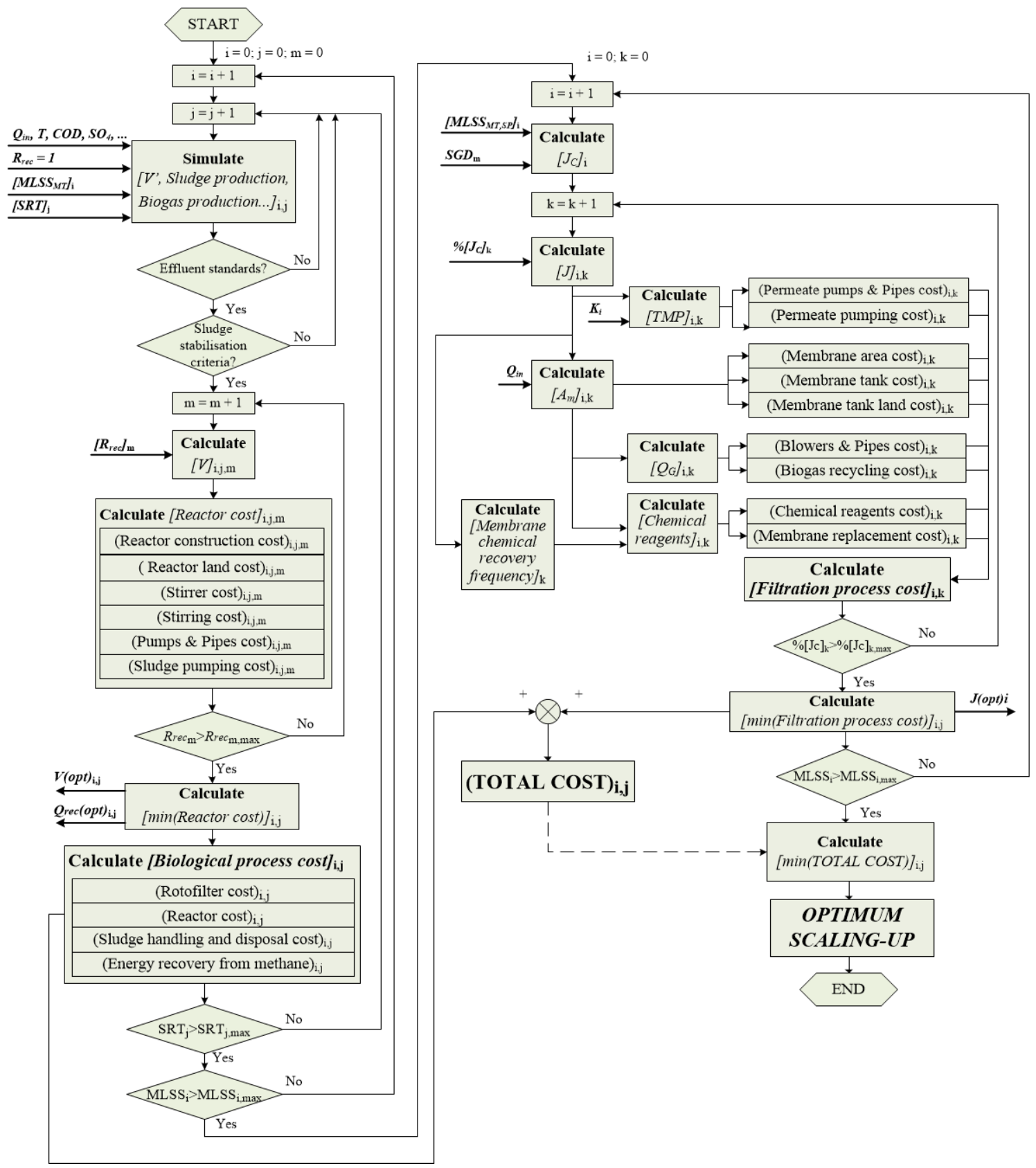

Figure A.1. Proposed design methodology for AnMBR technology. 